\title{
Water Management Strategies and the Cave-Dwelling Phenomenon in Late-medieval Malta
}

\author{
By KEITH BUHAGIAR
}

\begin{abstract}
NEW, NON-INVASIVE FIELD SURVEY suggests, for the first time, that farmers in $W$. Malta created extensive networks of underground water galleries for irrigation of the terraced field systems found in proximity to cave-settlements. Although none of the components of this landscape is scientifically dated, comparative research suggests that this sophisticated water-management system is similar to the qanat technology of the Islamic and Roman world. We have to consider seriously that this could be part of a new horticultural and technological package introduced during the Muslim and post-Muslim period between the I Ith-I 3 th centuries A.D. Overall, the paper is an attempt to gain an insight into Maltese exploitation of the perched aquifer before the late-Igth-century discovery of an alternative water source led to a dramatic shift in water management and production policies on the island. The associated evidence for cave-settlement is also reviewed. Many of the observations have an application to other parts of the island of Malta that possess a similar geological stratification.
\end{abstract}

In the arid Maltese archipelago, farmers have been almost exclusively dependent on the annual rainfall, aided by irrigation where the geology permits. The archaeological significance and relevance of narrow rock-cut tunnels tapping the perched aquifer had until my study of the medieval and early modern cave-settlements and water galleries in NW. Malta, south-west of the Great Fault (Fig. I), ${ }^{1}$ and further fieldwork since 2002, escaped scholarly attention. The geology of Malta enables cave-settlement as well as the availability of trapped underground water in some parts of the island. This paper describes the evidence for the cave-dwelling phenomenon in Malta, the underground galleries that exploited this water source, and their likely relationship. But first, some understanding is required of the local geology and hydrology.

\section{GEOLOGICAL GONSIDERATIONS}

The islands of the Maltese archipelago lie in the central Mediterranean Sea, $93.3 \mathrm{~km}$ south of Sicily, $357.3 \mathrm{~km}$ north of Tripoli and $289.7 \mathrm{~km}$ east of

\footnotetext{
${ }^{1}$ K. Buhagiar, Medieval and Early Modern Cave-Settlements and Water Galleries in North-West Malta South of the Great Fault - A Field Survey and Gazetteer (unpubl. M.A. thesis, University of Malta, 2002).
} 


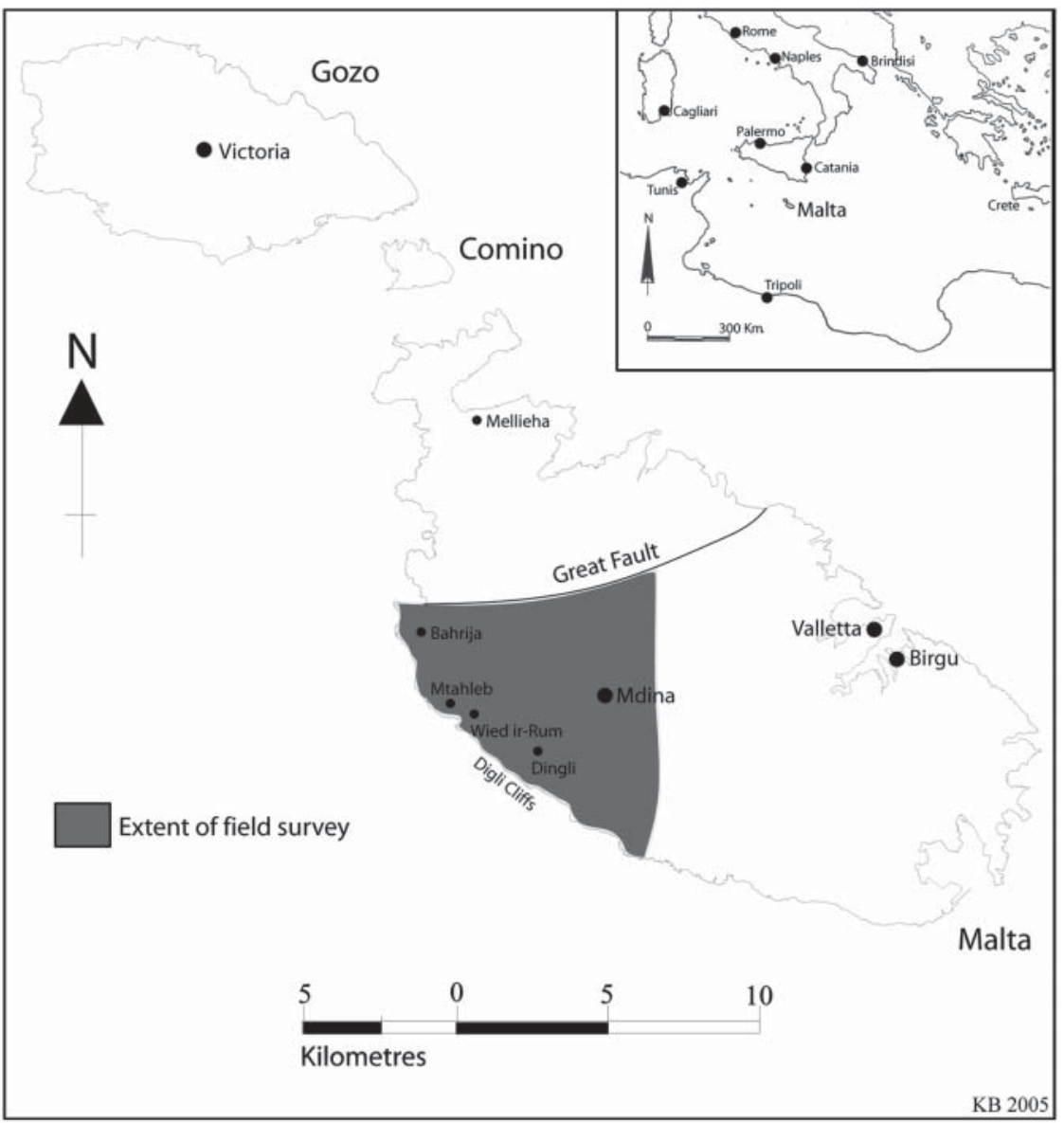

FIG. I

Map of the Maltese archipelago showing extent of field survey. Drawn by K. Buhagiar.

Tunis. Dating to the Oligo-Miocene era of the Tertiary period, the archipelago is entirely composed of sedimentary rock. ${ }^{2}$ Four distinct rock layers constitute the basic geology (Fig. 2). ${ }^{3}$ When undisturbed by land faulting, the horizontal stratification is:

- Upper Coralline Limestone (top);

- Blue Clay;

- Globigerina Limestone;

- Lower Coralline Limestone (bottom).

${ }^{2}$ G. Zammit-Maempel, An Outline of Maltese Geology (Malta, I977), i 8; M. Pedley, M. H. Clarke and P. Galea, Limestone Isles in a Crystal Sea (Malta, 2002), I 8.

${ }^{3}$ Pedley et al., op. cit. in note 2,35 . 


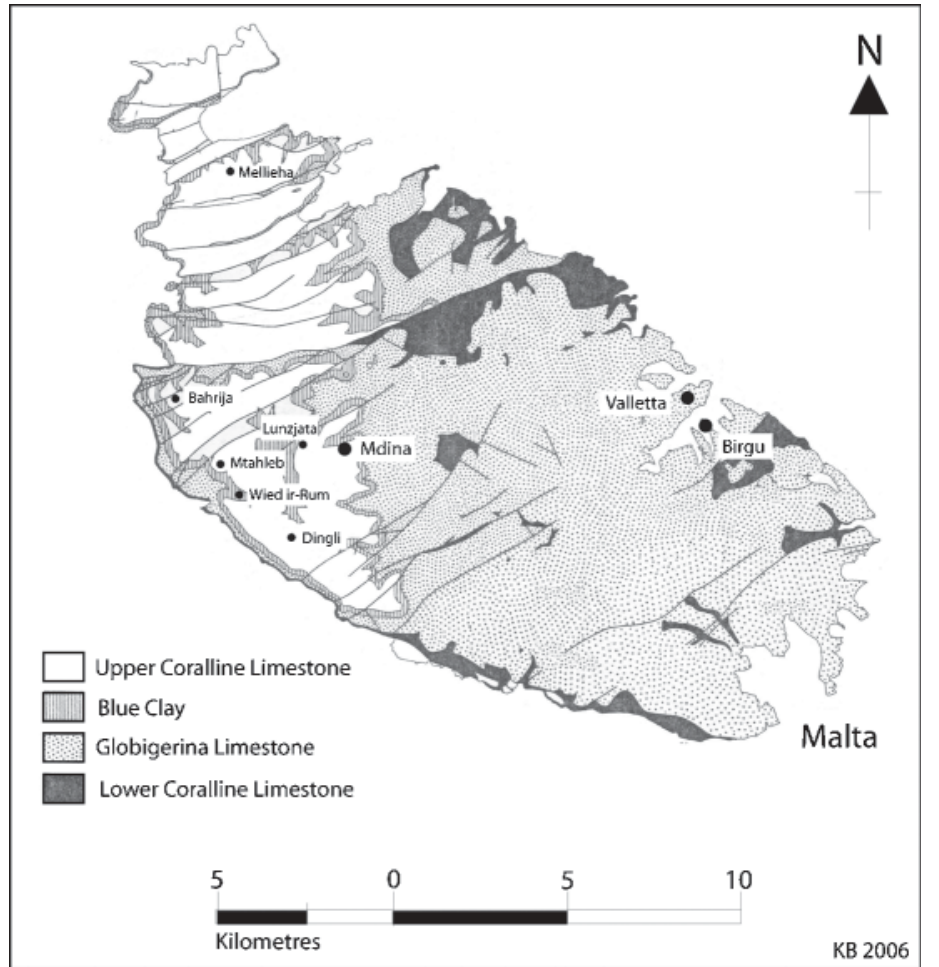

FIG. 2a

Geological map of Malta. After H. Bowen-7ones (op. cit. in note 4, 24); drawn by $K$. Buhagiar.
FIG. 2b

Bottom: Geological map of Gozo. After H. Bowen-fones (op. cit. in note 4, 24); drawn by $K$. Buhagiar.

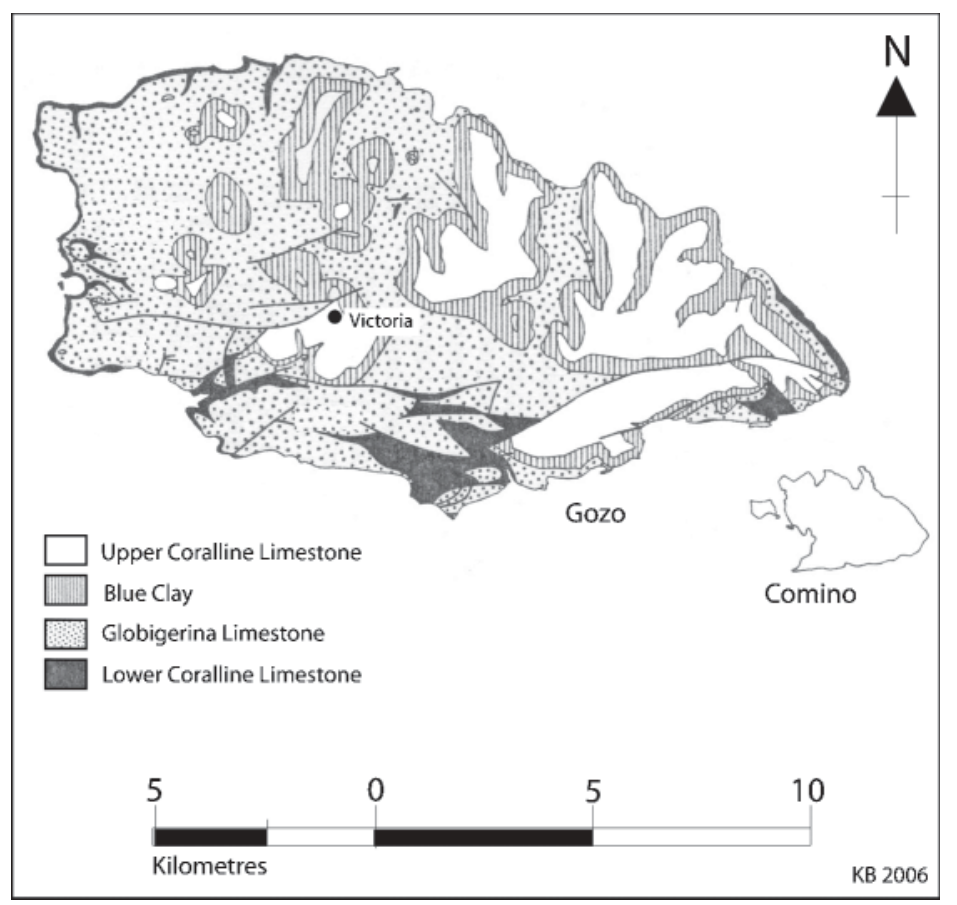


Lower Coralline Limestone, a hard and well-jointed rock-type, is commonly exposed in coastal cliff-regions alongside the western coast of Malta, but rarely occurs in inland locations. ${ }^{4}$

Globigerina Limestone outcrops cover large areas of land in central and south-eastern Malta and western Gozo, and constitutes the islands' main building resource. Its thickness varies considerably, from c. $205 \mathrm{~m}$ in south-eastern Malta, to the thinnest layer $(22 \mathrm{~m})$ recorded on Gozo.

Overlying this limestone is a Blue Clay deposit, which may reach a thickness of $70 \mathrm{~m}$. It is due to the presence of this clay deposit that a perched aquifer exists. An important and easily accessible resource, recognised since antiquity, numerous water galleries are dug into Upper Coralline or Greensand strata (see below) in order to extract water stored above this impermeable clay deposit. Clay was also used for local pottery production. It is only in the NW. section of the island of Malta that substantial clay deposits are available.

Upper Coralline Limestone is the youngest rock formation, and is carboniferous in nature. Four subdivisions of this rock stratum have been identified. Of particular importance to the study of the local cave-dwelling phenomenon is the Mtarfa Member, in which the majority of the caves are located. The thickness of this stratum varies from I 2 to $\mathrm{I} 6 \mathrm{~m}$ and is composed of massive to thickly bedded carbonate mudstones and wackstones. The carbonates become white and chalky and, due to their friable nature, can be easily quarried. The Ghajn Melel Member forms the lowermost Upper Coralline Limestone subdivision. Modern geological maps attach a glauconite-rich Greensand formation to this member.

Subject to considerable tectonic movement over the past millennia, microplate movement has shaped the relief of the Maltese Islands into a series of horst and graben zones (Fig. 3). ${ }^{5}$ The largest of these faults, the 'Great Fault', follows a SW./NE. axis and divides Malta into two distinct regions. A series of parallel ridges and valleys scar the area to the north, which contains both the steepest slopes and the largest expanses of near-level land in Malta. The prevailing geological deposit in this region is Upper Coralline Limestone. To its south, Globigerina Limestone deposits prevail, the eastern section of which consists of a series of valleys carved by streams descending to the central plains. ${ }^{6}$ The sides of faults and river valleys are dotted with caves, a significant number of which were probably used for the purpose of human habitation in the late Middle Ages.

Karst topography is locally restricted to regions containing Upper Coralline deposits (on both sides of the Great Fault) and is characterised by thick limestone strata containing sinkholes and, often, a network of caves. Karst subsidence structures form due to the erosion of calcium carbonate deposits, which readily dissolve by the action of rainwater, and gradually lead to the formation of

\footnotetext{
${ }^{4}$ H. Bowen-Jones, J. C. Dewdney and W. B. Fisher, Malta: Background for Development (Durham, I 96 I), 26; D. Waugh, Geography: An Integrated Approach (London, I 995), I 8o.

${ }^{5}$ Bowen-Jones et al., op. cit. in note $4,3 \mathrm{I}$.

6 Ibid., 34 .
} 


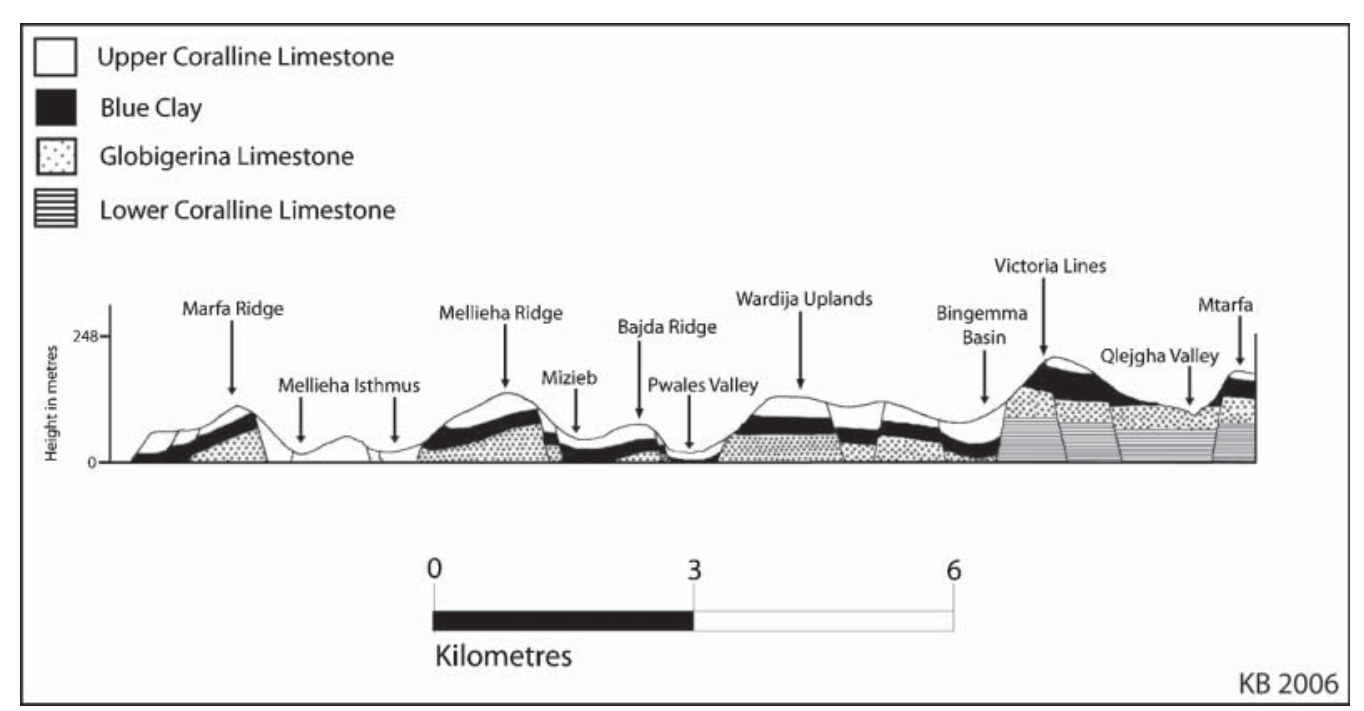

FIG. 3

N.-S. geological cross-section of northern Malta. After H. Bowen-Fones (op. cit. in note 4, 4I); drawn by K. Buhagiar.

subterranean caves. Collapse of a cave's roof leaves a large crater-like depression in the ground. ${ }^{7}$ The Maltese also adopted these subsidence structures for troglodytic settlements (Fig. 4).

\section{HYDROLOGY}

Today's Maltese climate is typically Mediterranean and is characterised by hot dry summers and warm wet winters. ${ }^{8}$ The annual temperature range is of approximately $\mathrm{I}_{5}^{\circ} \mathrm{C}$ and an average annual precipitation of $568 \mathrm{~mm} .{ }^{9}$ Insufficient and erratic rainfall creates regular drought conditions and makes water a limited resource (Fig. 5). The occurrence of climate shifts in the Mediterranean region since antiquity is still the subject of controversy and debate. Geological and historical evidence suggests that climatic conditions in Roman times were not appreciably different from those of the present day but were subject to temporary and minor, wetter and colder interludes. ${ }^{10}$

Rock strata such as Upper Coralline Limestone allow rainwater to percolate freely through them until its meets impermeable strata such as Blue Clay, or thick marly deposits embedded within the Globigerina Limestone layer. ${ }^{11}$ In

${ }^{7}$ A. Dolgoff, Physical Geology (New York, I 996), 426-8; M. Skinner, D. Redfern and G. Farmer, The Complete A-Z Geography Handbook (London, I 997), I64; Waugh, op. cit. in note 4, I80-1.

${ }^{8}$ Bowen-Jones et al., op. cit. in note $4,4^{8}-9$.

${ }^{9}$ Skinner et al, op. cit. in note 7 , i 88.

${ }^{10}$ C. Vita-Finzi, The Mediterranean Valleys - Geological Changes in Historical Times (Cambridge, i 969), I I 2-I4.

${ }^{11}$ Bowen-Jones et al., op. cit. in note 4, 43 . 

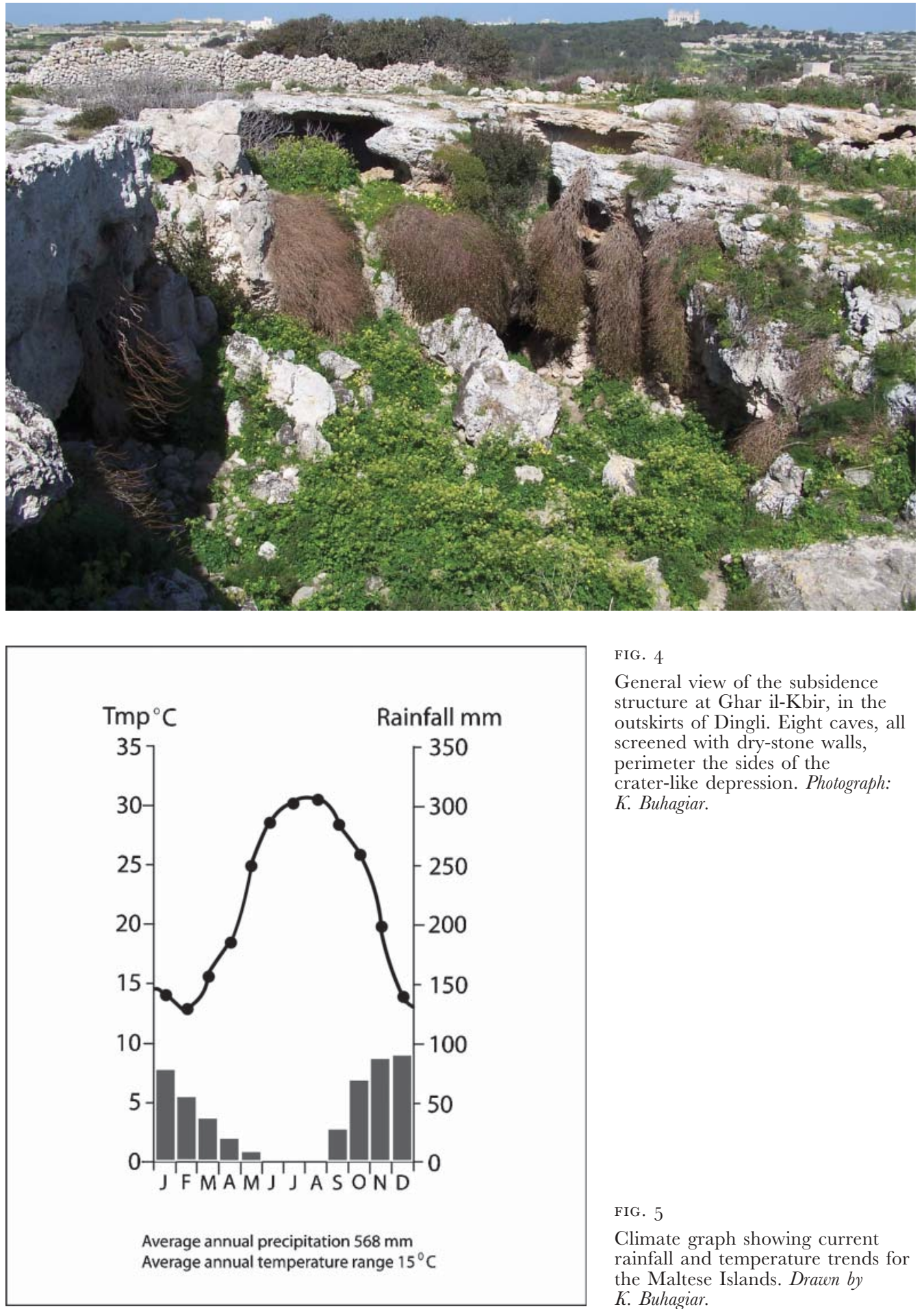

FIG. 4

General view of the subsidence structure at Ghar il-Kbir, in the outskirts of Dingli. Eight caves, all screened with dry-stone walls, perimeter the sides of the crater-like depression. Photograph: K. Buhagiar.

FIG. 5

Climate graph showing current rainfall and temperature trends for the Maltese Islands. Drawn by K. Buhagiar. 
the latter case, water percolation is slow and much of it is lost as runoff surface water. These underground water deposits, present within the Upper Coralline and Lower Coralline layers, provide Malta with its most abundant and reliable water resource: the 'perched aquifer' — water deposits available under Upper Coralline outcrops; and the 'mean sea level aquifer' — those present within the Globigerina Limestone and Lower Coralline outcrops. ${ }^{12}$ Only an estimated I $6-25 \%$ of the total water yielded annually through rainfall manages to percolate through the rock fissures and is eventually stored in either of the water tables. ${ }^{13}$ Today, boreholes are dug deep into the ground to pump water from both aquifers. Upon its discovery around I 30 years ago, the mean sea level water table became the island's main source of water supply, ${ }^{14}$ and since then full exploitation of the perched aquifer's potential for potable purposes effectively ceased.

\section{THE CAVE-DWELLING PHENOMENON}

In the late Middle Ages many Maltese were cave dwellers. ${ }^{15}$ Jean Quintin is the first known author to mention troglodytism in Malta. ${ }^{16} \mathrm{His}$ 'Insulae Melitae Descriptio', published in I536, shows his surprise at the great number of cave-dwellers on the island and probably reflects a long-established medieval life-pattern in the Maltese countryside. Rural and urban examples of latemedieval rock-cut churches also occur in Malta. ${ }^{17}$

The adaptation of caves into houses, burial places and cultic shrines represents an ancient Mediterranean practice, since prehistoric times. The troglodytic phenomenon was widespread in the region whenever environmental conditions were favourable - plentiful natural rock shelters and an abundance of easily quarried stone — not least because of the lack of building timber in such arid and semi-arid areas. Places such as Granada (Spain), Matera in Basilicata (Italy), Matmata (Tunisia) and the Cava D'Ispica (Sicily) show that, 'Mediterranean people have always chosen caves and grottoes, natural and excavated, as providing convenient, cool and often defensible dwellings, stores, stalls, cisterns, churches, burial places and catacombs'. ${ }^{18}$ Strabo, ${ }^{19}$ among other ancient authors, noted the habit of some African people of using caves as houses. When the Mediterranean coast of Africa was colonised by the Romans,

\footnotetext{
12 P. Schembri and A. Baldacchino, Ilma, Blat u Häja (Malta, I 998), 4 ${ }^{\mathrm{I}-3}$.

${ }^{13}$ Ibid., 4I; A. Azzopardi, A New Geography of the Maltese Islands (Malta, I 995), 75.

${ }^{14}$ Institute of Water Technology, Water Services Corporation, Malta.

${ }^{15}$ M. Buhagiar, 'Medieval cave-dwellings and rock-cut churches in Malta', Atrium., Mediterranean and Middle East Architectural and Construction Review, 3 (I984), I 7-22, I 7.

${ }^{16} \mathrm{~J}$. Quintin d'Autun, 'Insulae Melitae Descriptio', in H. C. R. Vella, The Earliest Description of Malta (Lyons I536) (Malta, I980), 3I, 39.

${ }_{17}$ Dusina recorded several cave-churches in the visitation report of I575. See G. Aquilina and S. Fiorini, Documentary Sources of Maltese History, Part IV_Documents at the Vatican, Malta: Visita Apostolica no. 5I, Mgr Petrus Dusina, 1575 (Malta, 200 I). See also M. Buhagiar, Christian Catacombs, Cult Centres and Churches in Malta to I 530, (unpubl. doctoral thesis, University of London, I 993), 346-59.

${ }_{18}$ A. T. Luttrell, 'Malta troglodytica: Ghar il-Kbir', Heritage, 2 (I 979), 46 I-5, 46 I .

${ }^{19}$ Strabo, The Geography of Strabo, Lib. vii, i 6, ed. and trans. H. L. Jones, The LOEB Classical Library (Cambridge, I 949), 25-6.
} 


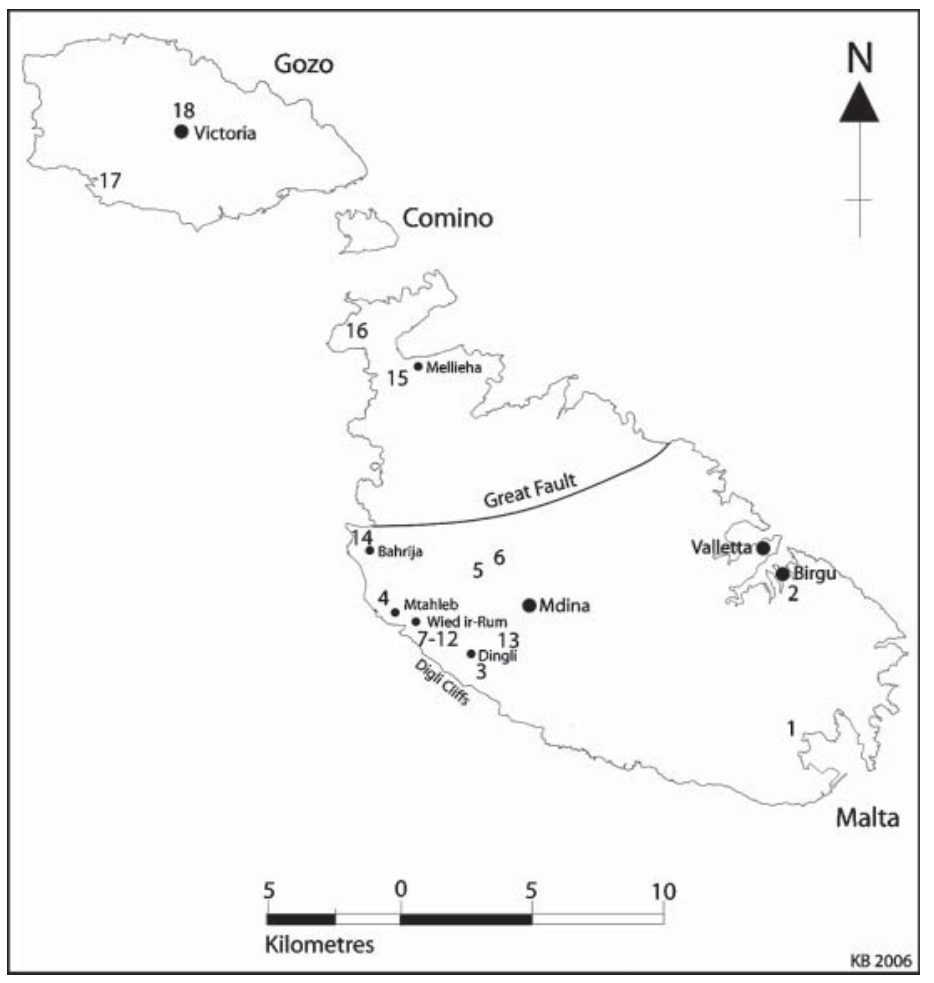

FIG. 6

Map of places mentioned in the text. I. Ghar Dalam. 2. Cottonera. 3. Ghar il-Kbir. 4. Tal-Merhla. 5. Nadur. 6. Bingemma. 7. Il-Qattara (La Kattara). 8. Ta' Callus. 9. Tax-Xieref. Io. Ta' Sasn Gakbu (Di S. Giacomo). I I. Ta' Baldu. I 2. Ghajn Tejtes. I 3. Dejr il-Bniet. I 4. Qlejgha tal-Bahrija. I 5. San Niklaw. i6. Latmija. i 7. Xlendi. i 8. Gozo Citadel. Drawn by K. Buhagiar.

they adapted themselves to the scarcity of timber and the availability of easily quarried rock. There are examples at Cyrenaica (Libya), Bulla Regis (Tunisia) and elsewhere of villas and other structures that are wholly or partially rock-cut. ${ }^{20}$

Ghar Dalam (Fig. 6), provides the first recorded instance for Maltese cave occupation, dated to c. 5000 B.c. ${ }^{21}$ As in medieval times, today's almost complete absence of woodland vegetation characterises the Maltese landscape, and we have seen how the geology and topography in NW. Malta could provide an ideal springboard for the widespread diffusion of troglodytism between the I I th to the i6th centuries. ${ }^{22}$ In the northern regions of Malta, people continued to inhabit caves until the first few decades of the 2oth century.

There are two distinct types of medieval cave-settlement in Malta: the adaptation of a natural karst depression for settlement purposes; and cliff-face settlements. My interpretation suggests cave usage varies from cultic worship to human habitation, animal pens or storage spaces often connected to agricultural usage, animal-driven mills (centimolo) and apiaries. ${ }^{23}$ A 2002 study on

\footnotetext{
${ }^{20}$ Buhagiar, op. cit. in note I 5 , I 7 .

${ }^{21}$ D. H. Trump, Malta: An Archaeological Guide (Malta, 2000), 90-2.

22 A. Messina, 'Trogloditismo Medievale a Malta', Melita Historica, ı:2 ( I 989), i o9-20, iog.

23 The apiaries are locally known as mgiebah (singular migbah); there is a concentration to the north of Malta in the Mizieb and Mellieha regions. See A. Camilleri, Fejn Jinzamm in-Nahal l-Imgiebah Jitrawmu: A Case Study in Industrial Archaeology (unpubl. undergraduate dissertation, University of Malta, 2003).
} 
the rural settlement of Simblija, in the outskirts of Dingli, incorporates many of the above mentioned features. ${ }^{24}$ It is an example of a late-medieval agricultural territory (viridarium), which still survives in its embryonic form, and consists of a combination of rock-cut and dry rubble constructions. The focal node of the settlement was an open square containing a structure probably used as a church, and a subterranean centimolo. ${ }^{25}$

Examples of karst feature settlements are Ghar il-Kbir (Fig. 4), and Latmija. These involve the occupation of one or more caves hewn into the sides of an open-air, natural rock-hollow. ${ }^{26}$ Because karst feature settlements occur in hard Upper Coralline deposits, hard geological formations frequently restricted cave enlargement.

Cliff-face settlements are located within the sides of ridges and valleys and involve the occupation of a series of natural or artificially enlarged caves (Fig. 7). Most of the caves surveyed fall under this category, and are often hewn

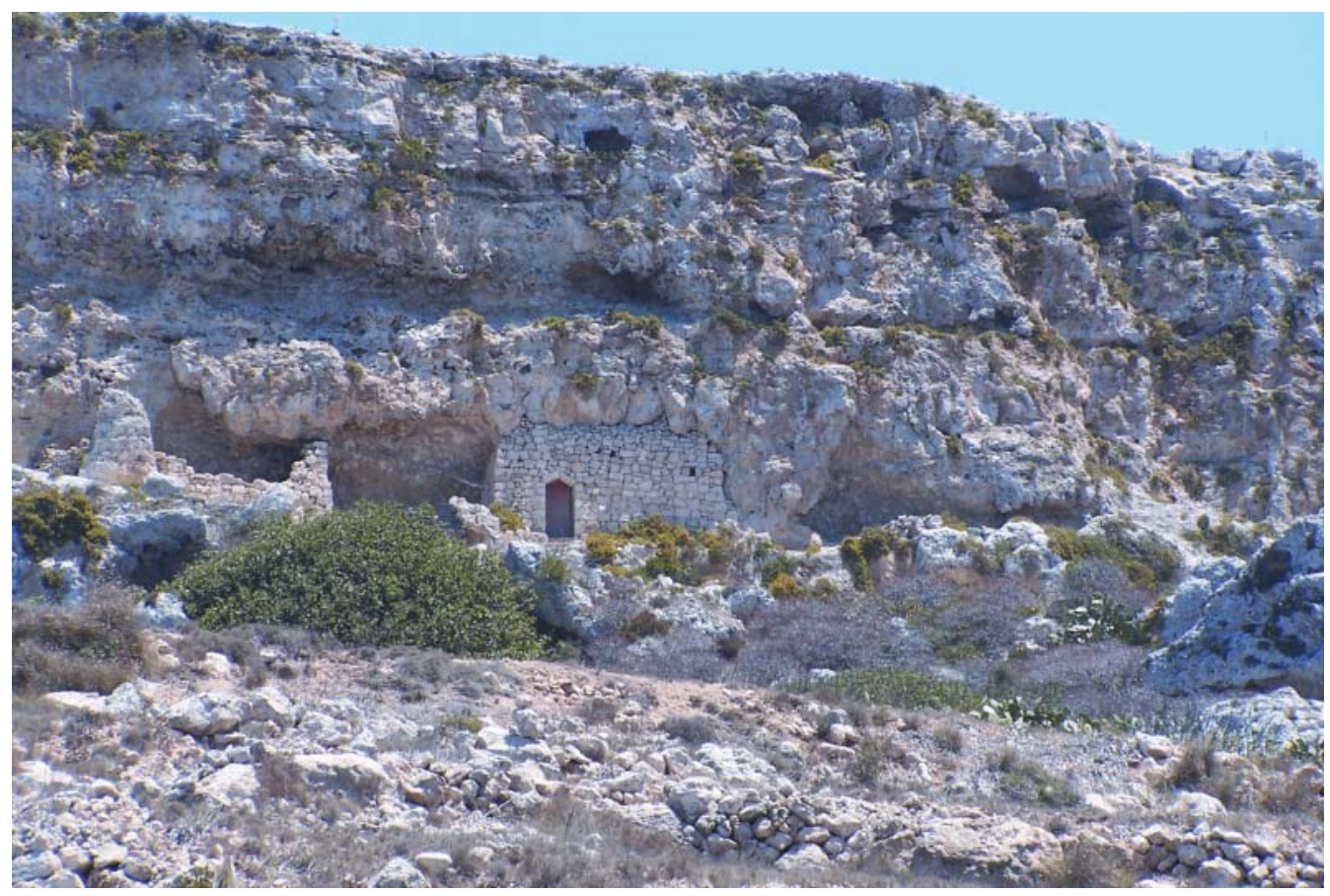

FIG. 7

General view of a cliff-face settlement dug into an Mtarfa Member deposit at Bahrija. Photograph: K. Buhagiar.

${ }^{24}$ P. C. Saliba, J. Magro Conti and C. Borg, A Study of Landscape and Irrigation Systems at Is-Simblija limits of Dingli, Malta E' Conservation Project (Malta, 2002). This study has partly succeeded in detecting several of the water galleries that service Wied ir-Rum valley, but it barely considers their antiquity and does not attempt to associate these underground hydraulic engineering works to qanats.

${ }^{25}$ M. Buhagiar, 'The Rural Tenement at Is-Simblija', Treasures Malta, 4:3 (2003), I 5-2 I . See also M. Buhagiar, The Late Medieval Art and Architecture of the Maltese Islands (Malta, 2005), $5 \mathrm{I}-4$.

${ }^{26}$ K. Buhagiar, The Ghar il-Kbir Settlement and the Cave Dwelling Phenomenon in Malta, (unpubl. undergraduate dissertation, University of Malta, I997), 64-70. 
into a surprisingly brittle Upper Coralline deposit (the Mtarfa Member). This formation is probably much easier to quarry than Globigerina Limestone and does not make the process of cave digging and enlargement as labour intensive and time consuming as commonly argued. The location of most cave-settlements suggests that their occupants possessed a sound knowledge of the local geology. Mtarfa Member deposits are commonly located only a few metres above the perched aquifer, which people often successfully tapped by means of an underground gallery, ensuring the settlement and the underlying fields had a perennial water source.

The majority of Maltese cave-settlements were probably subject to an organic type of development. Cave re-occupation and enlargement often involved the destruction of previous occupational phases and, in the absence of stratified deposits, dating is a difficult task. The presence of animal troughs easily identifies caves utilised in their last phase of occupation as animal pens. Caves containing no water troughs were used either for human habitation or for storage purposes. Tethering holes are common features associated with both the human and animal occupation of caves.

Caves frequently cluster together into units (Fig. 8), but isolated caves containing evidence of human or animal habitation are fairly frequent. A terrace, often present on the outside of cliff-face settlements, is a common addition aimed at linking two or more adjoining caves together. ${ }^{27}$ Dry- and wet-stone walls commonly screen a large section of the caves' entrance, leaving an arched or square-headed doorway as the only means of access. ${ }^{28}$ Narrow slits sometimes act as windows in the screening walls, but this is uncommon. Dry-stone constructions frequently partition cave interiors into a series of individual spaces. The exterior screening wall and sections of the caves' interior were occasionally plastered and whitewashed, but it is unknown if this was a widespread practice.

You access Maltese cave-settlements by means of one or more well-defined footpaths, some of which have a cobble-type paving. Numerous other similarly surfaced paths probably lie buried beneath modern concrete paving. In areas of difficult terrain, dry-stone ramps facilitated access to troglodytic settlements. The ramps, built parallel to the cliff-face, are similar in method of construction to dry-stone walls (Fig. 9). A soil and rubble infill, sometimes capped by means of a cobbled surface, bridges the gap between the cliff face and rubble wall, which is occasionally buttressed.

We can observe two distinct types of roofing strategies. When the dry-stone screening walls were built c. $0.6 \mathrm{~m}$ apart from the overhanging rock-ledge roofing the cave, the intermediate gap was bridged and sealed by means of

\footnotetext{
27 The cave-settlement of San Brinkaw, in the outskirts of Gharghur, San Niklaw, in the outskirts of Mellieha and San Pietru, in the outskirts of Naxxar, are all examples of cliff-face settlements which adopted the use of an artificially levelled terrace. See Buhagiar, op. cit. in note $26,72-86$.

${ }^{28}$ Wet-stone construction is where stones are secured in place by means of a mortar or a wet-earth rendering.
} 


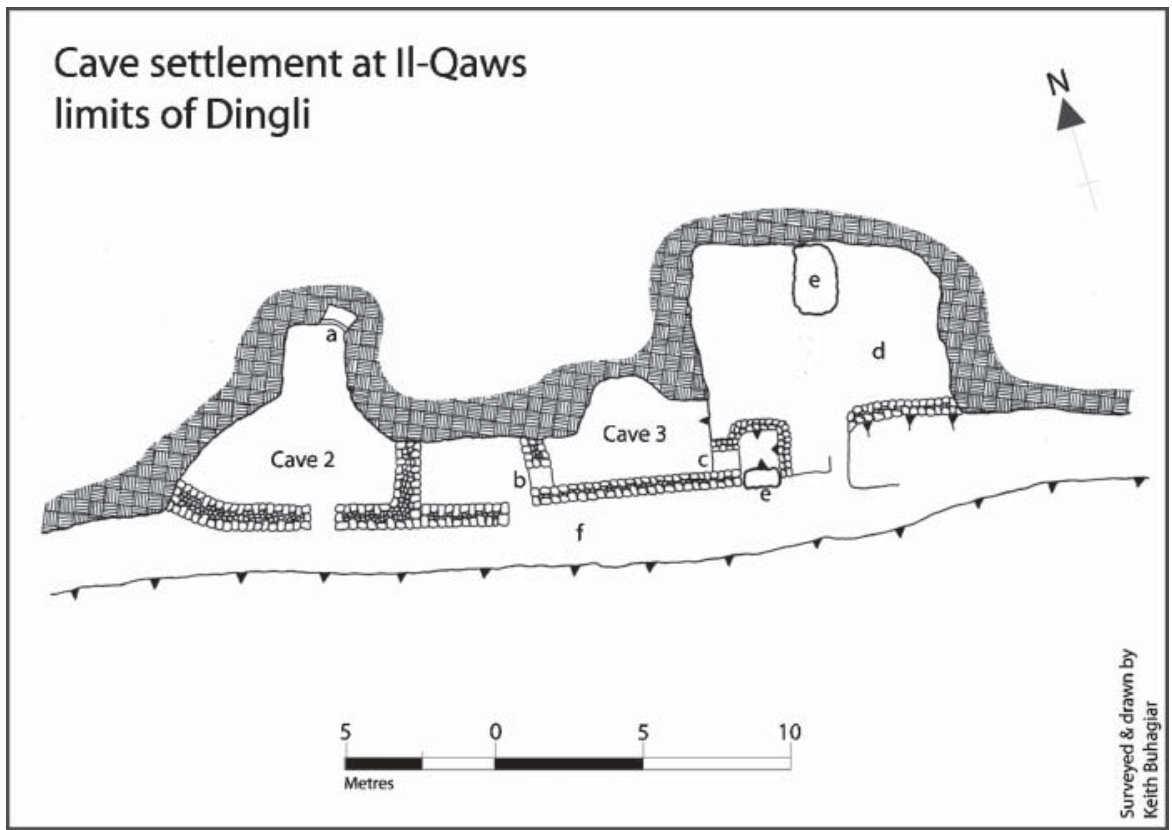

FIG. 8

Cave settlement at Il-Qaws, near Dingli. A. Animal-feeding trough. B. Doorway giving access to Cave 3 . C. Doorway giving access to unexplored vertical shaft. D. Partly rock-cut terrace. E. Rock boulders. Drawn by K. Buhagiar.

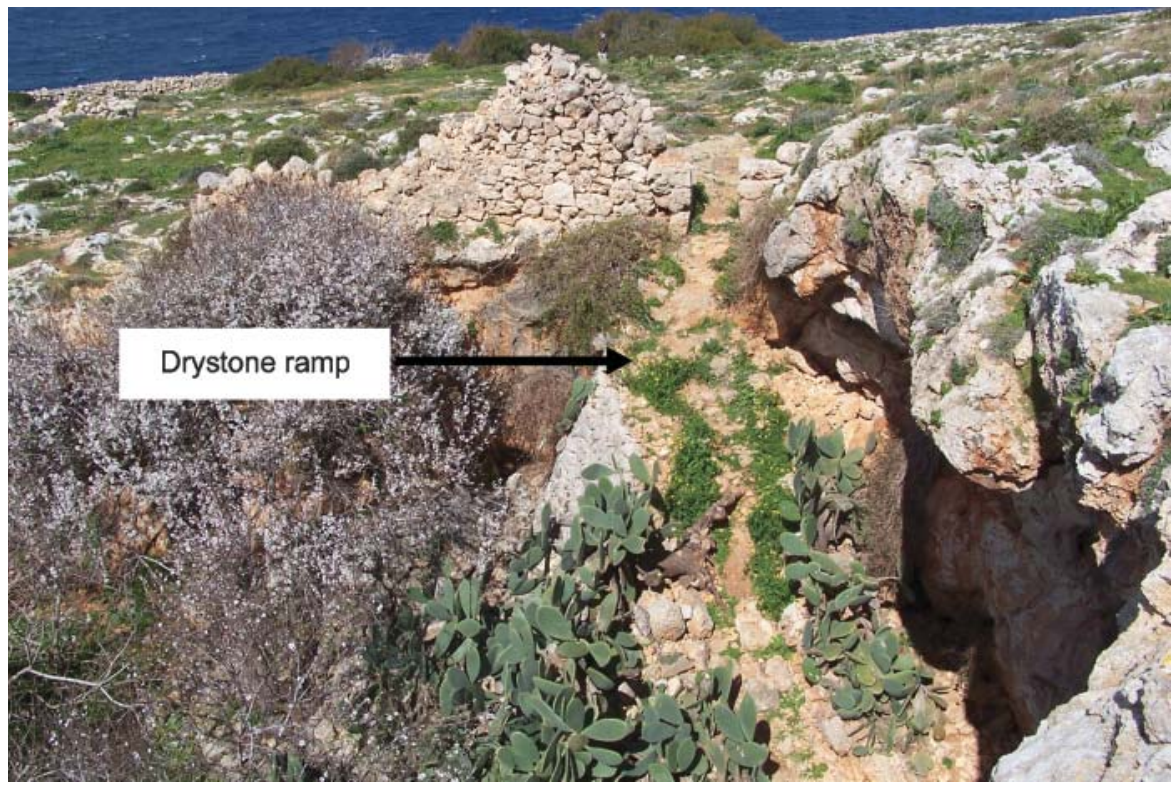

FIG. 9

Dry-stone ramp, preserving traces of a cobbled surface, giving access to the karst-feature settlement at Latmija, in the outskirts of Cirkewwa. Photograph: K. Buhagiar. 
roughly sawn, thin, ashlar slabs. These rested against the rock-face at an angle that generally varies between $20^{\circ}$ and $40^{\circ}$, secured in place by means of mortar, and made watertight with a deffun, ${ }^{29}$ or cocciopesto covering (Fig. Ioa). This technique was probably an attempt to gain more internal cave space.

A light roof structure often covered caves with screening walls built at a distance of over $0.7 \mathrm{~m}$ from the overhanging cave roof (Figs. Iob and c). It is unlikely that the roof structures recorded in this survey predate the first decades of the 2oth century, but the materials utilised and the construction methods employed are probably similar to the late-medieval roofing methods such as those recorded by Quintin in the I530s. ${ }^{30}$ Only dead vegetal material, easily obtainable from the surrounding countryside, was utilised. Unrefined carob and fig tree branches were often used as load-bearing members instead of timber beams, and were normally spaced between 0.6 to $0.8 \mathrm{~m}$ apart. Large quantities of dried bamboo reeds bridged the gap between each beam. A thick, compact layer of hay finally capped the roof, presumably tied to the beams in order to prevent its dispersal during rough weather. ${ }^{31}$

In sites located close to exposed clay deposits, it is possible that a thin clay layer lined roofs to improve waterproofing, but there is no evidence for this. The flat spaces above the outer part of cave units roofed by means of wooden and reed covers were frequently utilised as storage recesses for agricultural produce. Individual cantilevered steps attached to the outer skin of the cave screening wall provided access. People no longer construct light roofs and surviving examples are in a precarious state of repair. Unless preserved and adequately safeguarded these structures, built entirely out of perishable materials, will soon be lost.

For centuries, the rural inhabitants of the island lived almost at a subsistence level. Cave-settlements, like other surviving rural structures, portray a marked absence of unnecessary ornamentation: they were conceived to be practical, rather than fashionable. Rectangular recesses hewn into the rock walls of caves were frequently utilised for storage purposes. Notarial deeds dating to the I $4^{\text {th }}$ and $5^{\text {th }}$ centuries that describe the furniture content of Maltese late-medieval, above-ground houses lead us to believe that habitable caves also contained few items of furniture: perhaps a table, door and a couple of other wooden furnishings. Settlements sometimes spread out on different levels, making the best possible use of the limited space available.

Each settlement is unique and size, asymmetry and usage create endless combinations. Troglodytic settlements and any adjoining above-ground vernacular architectural elements are often the result of successful human interaction with the landscape: their builders did not try to conquer or crush nature,

\footnotetext{
${ }^{29}$ A mixture of ground pottery and lime.

${ }^{30}$ Quintin, op. cit. in note $\mathrm{I} 6,3 \mathrm{I}$.

31 A light roof structure roofing a cave on the west side of il-Qlejgha tal-Bahrija contains a compact layer of evenly spaced out, dried prickly pear pads, sandwiched between the reed and hay sections. Considering the fact that the prickly pear was introduced from the Caribbean, probably at a recent date, it appears that this plant matter was not available in the late medieval Maltese landscape. See J. Sultana and V. Falzon (eds.), Wild Life of the Maltese Islands (Malta, 2002), $6 \mathrm{I}$.
} 

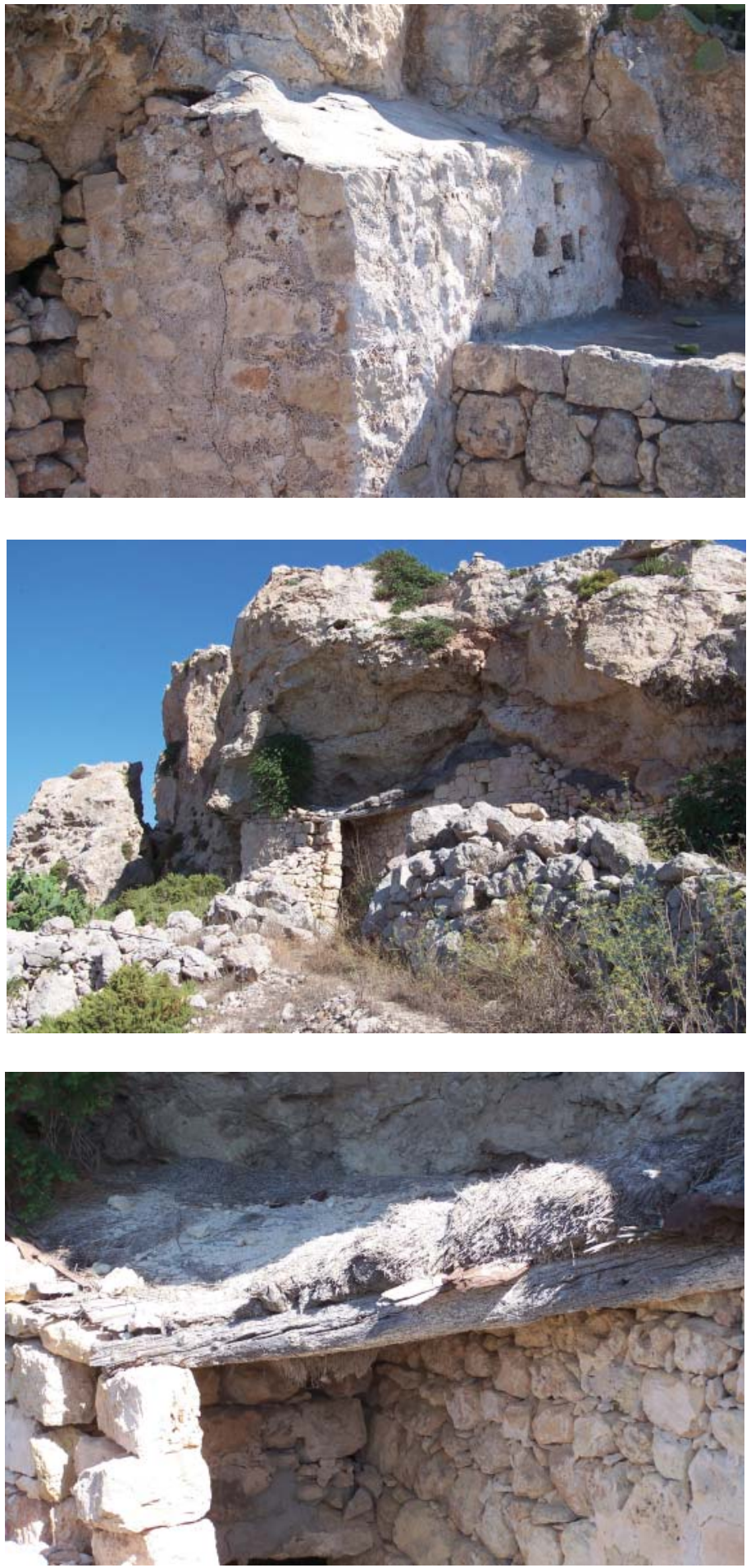

FIG. I Oa

Cave dug into the W. face of the il-Qlejgha tal-Bahrija promontory, in the outskirts of Bahrija. Detail of mortar rendering covering the ashlar slabs bridging the gap between the screening wall and the overhanging rock-face.

FIG. Iob

Exterior room of cave-complex at Bahrija partly roofed by means of a light roof structure.

\section{FIG. IOC}

Detail of light roof structure carried by timber beams at cave dug into the $\mathrm{W}$. face of the il-Qlejgha tal-Bahrija promontory, in the outskirts of Bahrija. Photographs: K. Buhagiar. 
but attuned to the challenge posed by topography. The Tal-Merhla cliff-face settlement and several other smaller cave-settlements in Dingli can be regarded as being a continuum rather than an addition to the landscape. Almost none are visible from above the overhanging rock ledge beneath which they are hewn and most are not easily identified from a distance. The siting of local troglodytic settlements parallels the Sicilian model. Available geological profile dictates the location of most cave-settlements in Sicily, and they are often sited in naturally defendable, difficult-to-reach places. ${ }^{32}$ Most settlements are hewn within exposed Mtarfa Member deposits and command unobstructed views of the surrounding area and the underlying fields, which in the past were probably tilled by the cave occupants themselves.

We cannot study Maltese troglodytic settlements in isolation. Cave dwelling is a widespread phenomenon, present throughout the Mediterranean and has characterised living patterns in the region until recent times. ${ }^{33}$ The practice of adapting caves as houses, or of hewing churches out of rock, provided little or no scope for architectural invention and development, and rock architecture was probably meant to reflect the influence of constructed buildings and not vice versa. ${ }^{34}$ The fact that individual cave-houses were often extended by the building of additional rooms in any available space in front of the cave entrance sustains this hypothesis. In such instances, the caves became animal pens or storage spaces for agricultural produce and implements. ${ }^{35} \mathrm{~A}$ few of the caves might have been also converted into apiaries, locally known as imigiebah. It is probable that in the late Middle Ages several cave-dwelling units were not utilised as permanent places of habitation as the occupants also possessed a house built of masonry. ${ }^{36}$

Cave-dwelling was probably not limited to rural areas. Carlo Castone Della Torre di Rezzonico wrote in a 1793 travel account that a number of families preferred to dig caves in the sides of the ditch surrounding Valletta and in the Cottonera area (an agglomeration of the Birgu, Bormla and Senglea settlements), rather than having to pay a housing rent. ${ }^{37}$

In general we know rather little about typology of the late-medieval Maltese rural house. ${ }^{38}$ In the I 530 os Quintin writes of 'African huts'. ${ }^{39}$ It is possible that he was referring to a primitive type of dry-stone building that is locally known

\footnotetext{
${ }^{32}$ A. Messina, 'Forme di Abitato Rupestre Nel Siracusano', in C. D. Fonseca (ed.), La Sicilia Rupestre nel Contesto delle Civilita’ Mediterranee (Catania, I 986), 245-50.

${ }^{33}$ A. Messina (op. cit. in note 22, I I O-I6) points out that local troglodytism parallels both its Sicilian and African counterparts. Maltese and Sicilian cave-dwellings are often dug sideways into the perpendicular wall of a ravine or hill, even though the use of dry-stone walls in Sicilian troglodytic settlements is limited for façade-screening purposes. For local caves that are fronted by a dry-stone wall enclosure, Messina suggests North African parallels.

${ }^{34}$ M. Buhagiar, 'Medieval Malta: its hypogea, cave churches and ecclesiastical buildings', in P. Calleja (ed.), Architecture in Malta I: Historical Aspects (Society of Architecture and Civil Engineering Students, Department of Architecture and Civil Engineering, University of Malta, Malta, I 986), 39-49, 44.

${ }^{35}$ Luttrell, op. cit. in note $\mathrm{I} 8,464$.

${ }^{36}$ Personal communication by Charles Dalli.

${ }^{37}$ J. Eynaud, Carlo Castone Della Torre Di Rezzonico — Viaggio Di Malta Anno I 793 (Malta, ig89), 6I.

${ }_{38}$ M. Buhagiar, book review of 'Mikiel Fsadni O.P., The Girna — The Maltese Corbelled Stone Hut', Melita Historica, I I:2 (I993), 2 I $3^{-1} 5$.

39 Ibid., 3 I.
} 


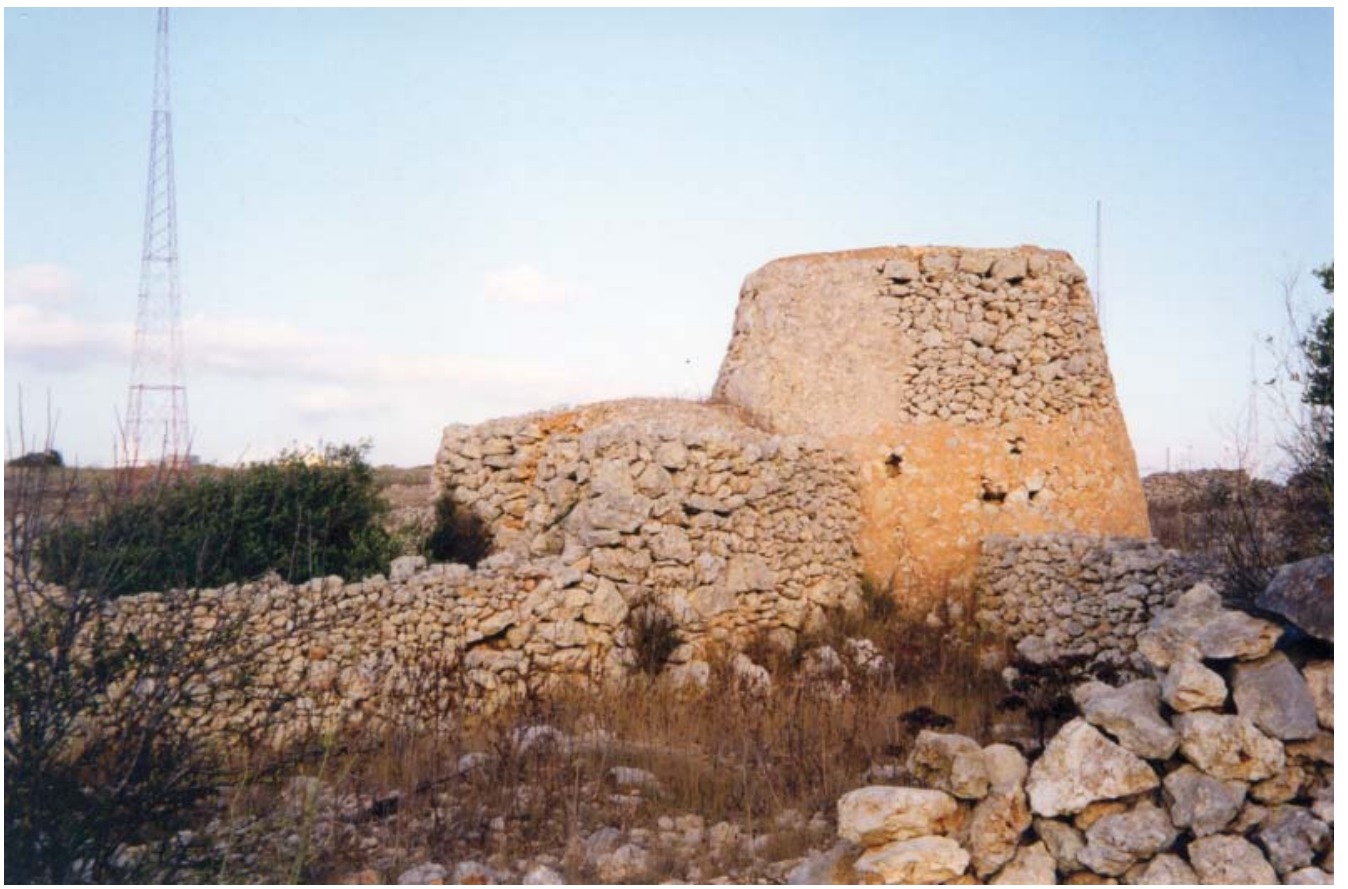

FIG. I I

A corbelled hut or giren cluster in the outskirts of Bahrija. Photograph: K. Buhagiar.

as the gima. ${ }^{40}$ This is a double-walled, corbelled stone hut, with an eastward facing door, and is shaped like a truncated cone or an igloo (Fig. I I). Squarish or rectangular derivatives of this structure are also recorded, but are scarce. Giren are unevenly distributed throughout Malta, mainly in the north and the west, but are rarely seen in Gozo. ${ }^{41}$ The present surviving giren are small and their probable usage in recent years was for the storage of agricultural tools. Larger giren though are known to have existed, and might have been used for long-term human and animal habitation. Giren also existed in clusters. The most impressive is the well-known complex at Bahrija, where three giren are huddled together to form a closely knit unit that is enclosed by a dry-wall precinct. Other such structures preserve mangers and stables while another cluster at In-Nadur, in the outskirts of Bingemma, gives the impression of the girna evolving into a farmhouse-like structure known locally as razzett.

${ }^{40}$ M. Buhagiar, 'Post-Muslim Malta: a case study in artistic and architectural cross-currents', I $3^{-} 3^{\text {I }}$ in S. Fiorini and V. Mallia-Milanes (eds.), Malta: A Case Study in International Cross-Currents (Malta, I 99 I), I6-I8.

${ }^{41}$ C. J. Jaccarini, Ir-Razzett: The Maltese Farmhouse (Malta, I998), 2-3. Id., 'Giren and Mgiebah of Mellieha', I69-84 in J. Catania (ed.), Mellieha Though the Tides of Time (Malta, 2002), I69-73; M. Fsadni, The Girna - The Maltese Corbelled Stone Hut (Malta, I 992), 9-14. 


\section{WATER-MANAGEMENT STRATEGIES}

The known historical documentation on the water sources and management employed for domestic and agricultural use in late-medieval Malta is limited. The earliest record does not predate $\mathrm{I}_{4} 67$ and we cannot regard the surviving documentation as a representative sample of what probably existed. ${ }^{42}$ Notarial deeds of the $15^{\text {th }}$ century contain information on a multitude of aspects related to day-to-day life, ${ }^{43}$ including water storage and management. ${ }^{44}$ Notarial deeds of the I6th century might yield more evidence in this respect, but their investigation has still to be systematically undertaken.

In the absence of further primary documentation, we may glean precious information from a detailed analysis of Della Descrittione di Malta published by A. F. Abela in $1647 .{ }^{45}$ A study of toponyms can also be richly rewarding. Godfrey Wettinger, also hints at the presumed relevance of tithal accounts and the records of the Bishop's Court. ${ }^{46}$

What follows now concentrates on one mode of water retrieval and management harnessed for the purpose of irrigation identified in several rural and urban areas of Malta possessing the necessary geological stratification, taking Wied ir-Rum in the outskirts of Dingli as a case study.

As we have seen, the arid nature of the archipelago made farming difficult. Dry-farming was predominant in medieval Malta and the success of the cultivated crop was entirely dependant on the annual rainfall and the adoption of contour ploughing. Peasants suffered widespread financial hardship when rains failed, as was the case for three consecutive years in the latter half of the $1460{ }^{47}$ But where geology permitted, they employed irrigation. This is proved by the survival in the Maltese language of the words saqwi and baghli - terms which distinguish the irrigated from the non-irrigated landscape. ${ }^{48}$ Gnien (e.g. Gnien Bazili), and Ghajn (e.g. Ghajn Tejtes) toponyms are common references to areas containing one or more water springs, within which horticulture and viticulture were commonly practiced. ${ }^{49}$

In his section on 'Malta Inabitata' (or 'Uninhabited Malta'), Abela lists numerous Ghajn and Gnien toponyms, most of which are located in north-western Malta in the area covered by this field survey. ${ }^{50}$ Abela refers to Gnien toponyms

\footnotetext{
${ }^{42}$ G. Wettinger, 'Agriculture in Malta in the Late Middle Ages', Proc. History Week I 98 I ( I982), I-48, I.

${ }^{43}$ Late medieval rural economy and related issues such as land ownership, the leasing of property, employment agreements, the sale of farm animals and other agricultural products are discussed in ibid., $\mathrm{I}-48$.

${ }^{44}$ Several contracts in the recently published notarial deeds of Notary Giacomo Zabbara show entries for 'aqua', 'aque', 'aqueductus', 'aquarum pluviarum conductus', 'cisterna', 'conductus' and 'irrigacio'. See S. Fiorini, Documentary Sources of Maltese History: Part I Notarial Documents — No. I, Notary Giacomo Zabbara, R494/I (I): I 486-I 488 (Malta, I 996); id., Documentary Sources of Maltese History: Part I Notarial Documents - No. 2, Notary Giacomo Zabbar, R494/I(II-IV) I 494-I 497 (Malta, I 999).

${ }_{45}$ G. F. Abela, Della Descrittione di Malta Isola nel Mare Siciliano (Malta, I 647), 64-74.

${ }^{46}$ Wettinger, op. cit. in note $42, \mathrm{I}$.

47 Wettinger, op. cit. in note 42,3 .

${ }^{48}$ M. Serracino-Inglott, Id-Dizzjunarju Malti u tezawru ta' malti mhaddem (Malta, 200o), 5o6, 34; T. F. Glick, Islamic and Christian Spain in the Early Middle Ages (Princeton, I979), 83-4; Wettinger, op. cit. in note 42, 3.

${ }^{49}$ For a list of 'gnien' toponyms, see G. Wettinger, Place-Names of the Maltese Islands ca. I 300-I80o (Malta, 200o), I 5 I-64. For a list of 'ghajn' toponyms, see id., I 8 I-93. Wettinger, op. cit. in note $42,3-4$.

${ }_{50}$ Abela, op. cit. in note $45,64-75$.
} 


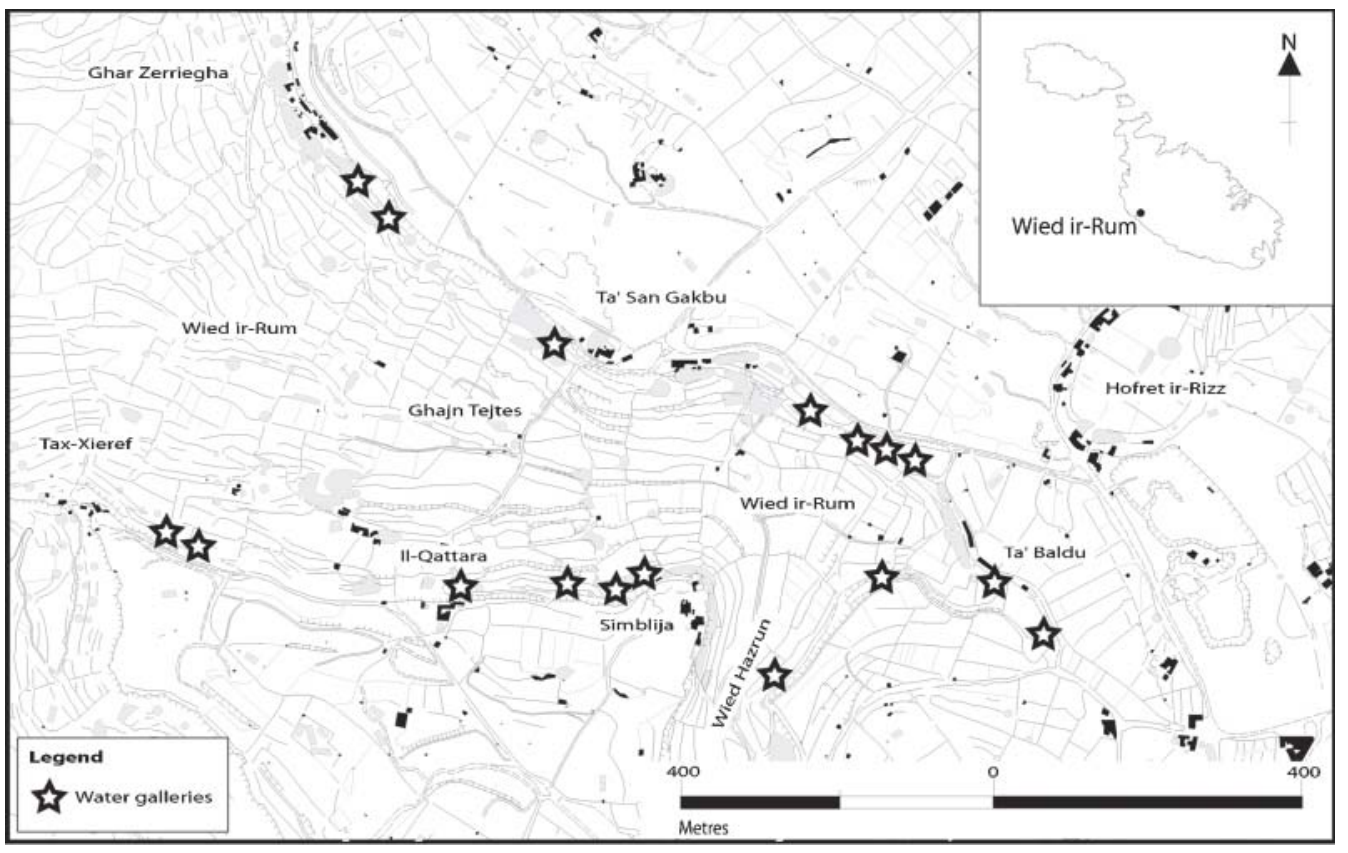

FIG. I 2

Spatial distribution of water galleries in Wied ir-Rum, in the outskirts of Dingli. Drawn by K. Buhagiar.

as Giardini. One of the most fertile districts of the island, well renowned for its water sources and the quality of the fruit produced within, is Wied ir-Rum (Fig. I 2). The valley is composed of a number of adjoining giardini that Abela groups accordingly. He describes Wied ir-Rum as, 'Valle de' Christiani Greci, amena, e piena di giardini d'ambe le parti, che rappresentano all'occhio una bellissima veduta, e somministrano al gusto buonissime frutta' [The valley of the Greek Christians which abounds with horticultural gardens and which presents the visitor with a beautiful view and good tasting fruit]. The giardini in question are those of 'La Kattara', 'Tal Callus', 'Ta Scieref', and 'Di S. Giacomo' (modern-day IlQattara, Simblija, Tax-Xieref and Ta' San Gakbu respectively). Abela also mentions an adjoining giardino of 'Ta' Baldu', in his list of places falling outside the inhabited areas of the island. In order to emphasise the availability of water sources and quality of the fruit produced within the garden of Ta' Baldu, this is listed separately, even though located in very close proximity to S. Giacomo. ${ }^{51}$ In Abela's time, all giardini within the valley were possibly capable of producing two or more crop yields annually, if adequately managed.

I identified two distinct types of water sources in Wied ir-Rum. The first consists of a water spring flowing through the lowest section of the valley; its level is subject to seasonal fluctuations depending on the annual rainfall. This source originates from surface runoff and water leakages in the perched aquifer system. In both instances, the topography of the surrounding area channels

${ }^{51}$ Abela, op. cit. in note 45,65 . 
water into the lowest section of the valley. The spring flows underground during most months of the year and in Wied ir-Rum, as with similar sources elsewhere on the island, has been scarcely tapped for agricultural use.

The second type of water source originates from within horizontal galleries hewn into Mtarfa Member deposits at right angles to the rock-face, located in the upper terraced sections of the valley. Galleries are generally easily identifiable from their rectangular-shaped rock-cut entrance that is on average $0.8 \mathrm{~m}$ wide and a bit more than I.5 m high. There are several instances, however, where the gallery entrance lies in a cave's interior. The Ghar ta' Baldu and il-Qattara - two artificial water springs located in Wied ir-Rum - are cases in point. The depth of galleries is unknown, but several of the recorded water tunnels may be well over half a kilometre deep. ${ }^{52}$ In order to ease the flow of the water retrieved from the perched aquifer, a canal is often carved into the floor of the gallery.

All galleries provide the surrounding area with a perennial water source, though the volume of the retrieved water varies from gallery to gallery. The majority of the galleries surveyed yield a surprising volume of water during the dry summer months, even though this is subject to yearly rainfall fluctuations. They are generally level with the highest terraced field on the valley side, with water transported from their entrance to the adjoining and underlying fields by means of stone canals. Water reservoirs are sometimes in the immediate proximity of the gallery's entrance (Fig. I3). In instances where galleries are located in a cave interior, these are often fronted by an internal, partly rock-cut, partly masonry built reservoir (Fig. I4). Some of the local galleries have vertical shafts that pierce the roof of the galleries at intervals. ${ }^{53}$

At Wied ir-Rum alone, eighteen water galleries have been identified (Fig. I 2). The galleries supply the valley with an abundant water supply and are the life-source supporting the existence of an ecological niche which would otherwise not survive. Another fifteen galleries are hewn into Mtarfa Member deposits in the upper cliff-face section at Dingli. A large concentration of identical galleries has been identified at Mtahleb and an isolated presence of galleries has been recorded elsewhere in the survey area. ${ }^{54}$ Other galleries built on the same hydrological principle and technology as those found in Wied ir-Rum are recorded in areas of Malta and Gozo possessing the necessary geological stratifications. ${ }^{55}$

\footnotetext{
52 The main gallery may fork into one or more minor arteries, and their depth is difficult to calculate. Some are too deep to wade through. Their fuller investigation carries significant risks.

${ }^{53} \mathrm{I}$ have not yet identified the full extent of this practice.

54 Buhagiar, op. cit. in note $\mathrm{I}, 8 \mathrm{I}-3$.

55 The following list is by no means exhaustive, and only makes reference to galleries known to the author at the time of writing: Ghar Ilma (GR 29 89), Dwejra (GR 273 90I). Another gallery is located on the Qala promontory overlooking Hondoq ir-Rummien — pers. comm. Frank Theuma. A brief reference to water galleries is made by the hydraulic engineer Vincenzo Mercieca. See V. Mercieca, 'Brevi Cenni sulle acque sorgive e sugli acquedotti dell'Isola di Malta', Archivum Melitense, 8:2 ( I930), I-24, 5. Temi Zammit mentions galleries hewn into the perched aquifer, and makes reference to a water gallery at Ta' Baldu. The hydraulic engineer Osbert Chadwick personally examined several water tunnels in 1883 and I884 and reached the conclusion that these could retrieve water from the perched aquifer because the waters of percolation were arrested and gathered by local beds of clay. The dating of the galleries was attempted by neither Temi Zammit, nor Osbert Chadwick. See T. Zammit, The Water Supply of the Maltese Islands (Malta, I 93 I), 37-43; O. Chadwick, Report on the Water Supply of Malta (Malta, I 884), 24.
} 

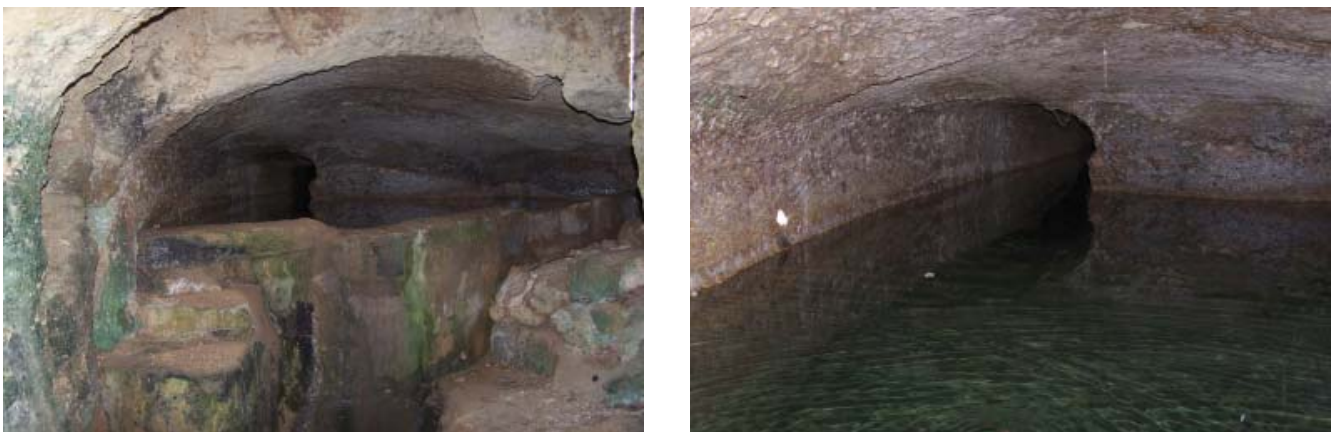

FIG. I3

Left: Water gallery exterior and fronting reservoir at Wied Liemu, in the outskirts of Rabat. Right: Detail of entrance of water gallery overlooking Wied Liemu, in the outskirts of Rabat. Photographs: K. Buhagiar.

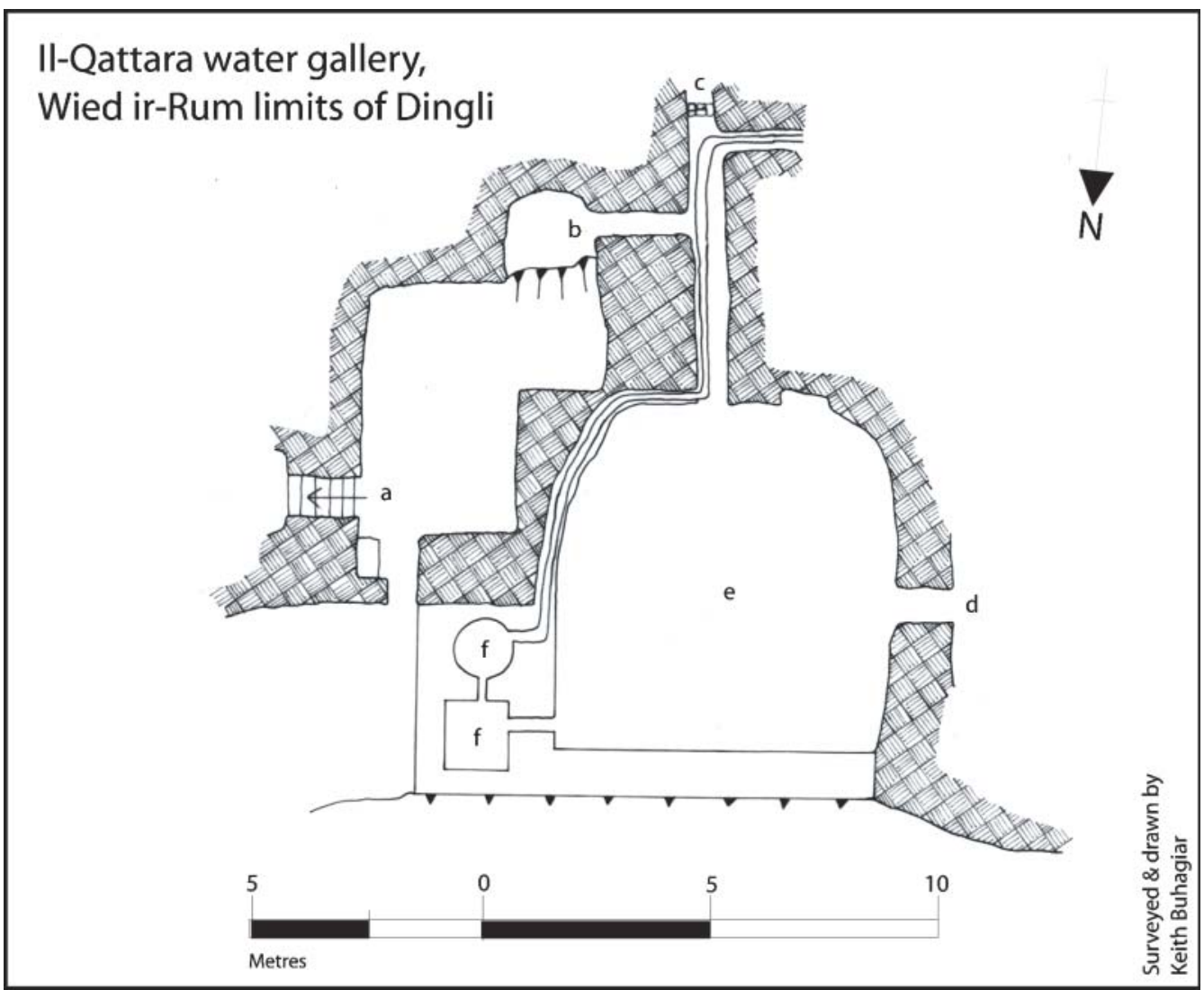

FIG. I 4

The Il-Qattara water gallery in Wied ir-Rum, fronted by a partly rock-cut, partly masonry built reservoir. A. Steps leading up to adjoining cave. B. Elevated rock-recess giving access to gallery. C. Walled-up gallery. D. Unexplored subterranean space used for water storage. E. Water reservoir. F. Water-settling vats. Drawn by K. Buhagiar. 
Such galleries are also recognised in the fortified settlements of the Gozo Citadel and Mdina, the medieval capital of Malta. Research is ongoing, but the emerging pattern is that their water supply mainly depended on a series of galleries tunnelling beneath the bastions. A series of vertical shafts piercing the galleries' roofs at intervals allowed the retrieval of the extracted water from within the fortified settlements. A case in point is a well at Palazzo Falsone - a late-medieval house of distinction in Mdina, which gives access to a probable water gallery. ${ }^{56} \mathrm{By}$ 'pozzo di aqua viva' or a well of running water, Abela writing in 1647 also probably refers to a number of such water sources. ${ }^{57}$ In areas where the perched aquifer was unavailable, the only possible modes of water collection were through the collection of surface run-off water and its storage in underground cisterns, and the accidental tapping of the mean-sea level aquifer. ${ }^{58}$

Numerous galleries, some of which are similar if not identical in hydraulic principle and technology to the Maltese galleries, are widely diffused in the Islamic and, before it, in parts of the Roman world. Comparison with qanat and cuniculi hydrological methods concludes that the Maltese galleries are very similar in method of construction, location and geology to qanat typology.

\section{QANAT AND CUNICULI}

The lack of a secure perennial water source was a shared concern in Mediterranean and Near Eastern settlements. Water is acknowledged as the most important variable in Mediterranean food production, and its storage and management was regarded as a priority by many societies. ${ }^{59}$ Islamic agricultural technology succeeded, even though on a micro-regional level, in the development of a hydrological system enabling a reliable perennial water source to extend the winter growing season well into the summer months. This concept of irrigation, also known as the 'invention of summer', depended on the construction of a system of underground conduits or canals, known as qanat, which tap underground aquifers and channel out the water to form springs (Fig. I 5) ${ }^{60}$

Qanat (or qanawat) means lance or conduit, is Arabic in origin and derives from the Akkadian qanu. ${ }^{61}$ Qanat are not an Arabic hydrological invention and, prior to the diffusion of Islam in the 7 th century A.D., they were used as an aid to agriculture on a micro-regional level in Persia, Mesopotamia, eastern Arabia

\footnotetext{
${ }^{56}$ Buhagiar 2005, op. cit. in note 25, I I 2-I 3 .

57 Abela, op. cit. in note 45, 33 .

${ }^{58}$ A paper investigating surface runoff water harvesting and farming in Santa Maria Bay, Comino will be published by the author towards the end of 2007 in Malta Archaeol. Rev.

${ }_{59}$ P. Horden and N. Purcell, The Corrupting Sea - A Study of Mediterranean History (Oxford, 200o), $237-8$.

60 Ibid., 238.

${ }^{61}$ P. W. English, 'The origin and spread of qanat in the Old World', Proc. American Phil. Soc., I I 2 (I968), I 70-8I; A. T. Hodge, Roman Aqueducts छ Water Supply (Melksham, 2002), 2 I.
} 


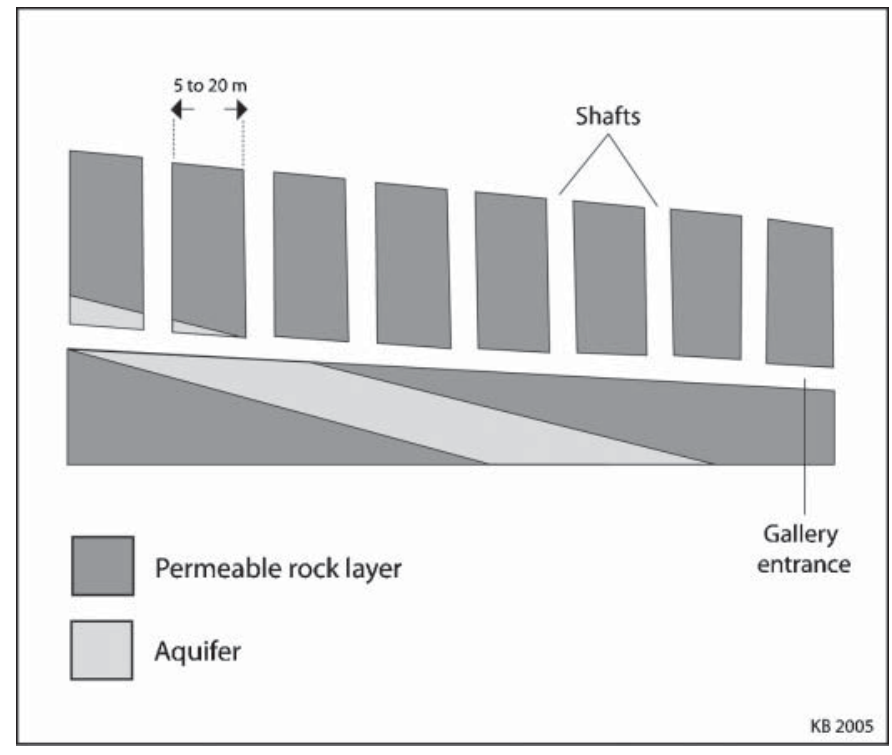

FIG. I5

Profile of a qanat system. Drawn by K. Buhagiar.

and up to a limited extent, a few parts of Egypt. ${ }^{62}$ The Greek historian Polybius (c. 200-I I 8 B.c.), refers to a dense network of underground canals in Iran that conveyed a water supply to places which were previously not irrigated. The galleries were already ancient in Polybius's time and the population making use of these hydrological devices did not know where their supply came from. An oral tradition recounted by the inhabitants, and which Polybius holds as true, narrates that when the Persians were the rulers of Asia they gave the right to cultivate the land for the duration of five generations to those who conveyed a supply of water to previously un-irrigated places. ${ }^{63}$

Hydrological technology apparently first experienced a stage of limited diffusion in the Mediterranean region in the classical era, especially in areas under Roman domain. ${ }^{64}$ It was only with the onset of Arabic expansion during the course of the 7 th and 8th centuries that the qanat technology and other hydraulic engineering feats known only to limited areas of the old world became

\footnotetext{
${ }^{62}$ A. M. Watson, Agricultural Innovation in the Early Islamic World (Cambridge, I983), i 07; see also Glick, op. cit. in note 48, 21 7-r 8. Pierre Briant of the Collège de France in Paris is heading an excavation in the Western Desert of Egypt, south of the Khargeh Oasis in the region of Dush. Qanat were recently discovered in an area where the Persian (Achaemenid) influence has long been known. Until recently, however, it was not possible to date with certainty the qanats to the Persian occupation of the area. Recent archaeological discoveries at Ayn Manâwîr, $3 \mathrm{~km}$ to the west of Dush, have linked the qanats with near-certainty as hydrological innovations introduced into the region during the Achaemenid occupation of the area. See M. Wuttmann, 'Les qanãts de 'Ayn-Manâwîr (oasis de Kharga, Égypte)', I o9-35 in Pierre Briant (ed.), Irrigation et drainage dans l'Antiqité, qanãts et canalisations souterraines en Iran, en Egypte et en Grèce, séminaire tenu au Collège de France sous la direction de Pierre Briant (Collège de France, 200 I).

${ }^{63}$ Polybius, The Histories, Lib. x, 28, ed. and trans. W. R. Paton, The LOEB Classical Library, Iv (Cambridge, I 954), I 69-7 I.

64 T. F. Glick, Irrigation and Society in Medieval Valencia (Harvard, I970), I 75-6.
} 
widely diffused in North Africa and parts of western Spain. ${ }^{65}$ North African qanat are known as foggara or kariz, but in Morocco they are commonly called hattaras. ${ }^{66}$ An alternative view is that qanat technology had already penetrated as far west as Algeria in antiquity. ${ }^{67}$ Either way, even though the Arabs may have invented little themselves, they preserved, refined, developed and intensified technological practices they inherited from the ancient world. ${ }^{68}$

Qanat are gravity-fed water sources situated at a useful altitude in relation to the workable land and have the advantage of using less slope than the surface canals. They avoid the loss of water through the means of evaporation and overcome the need for the construction of water-lifting devices similar to the dam and the noria. ${ }^{69}$ The digging of qanats is usually restricted to arid lands where water irrigation is extremely scarce and involves a major investment in agricultural intensification. ${ }^{70}$ Qanat are not immune to variations of flow, especially if the seasonal aquifers of alluvial fans are tapped, and are often considered to be technical, costly and labour intensive, even though they have a transforming effect on productivity. ${ }^{71}$ While failing to comment on the approximate duration of a qanat-building project, Beekman, Weigand and Pint hold an alternative view about how labour intensive the qanat were, because the gallery and shafts would have posed natural physical constraints on the number of people employed on the project. They suggest that the construction team would have seldom numbered more than six to ten members, and split between above- and below-ground workers. ${ }^{72}$

Construction generally involved sinking a series of wells or shafts, which were at a later stage connected by an underground canal (Fig. I5). In fact, only the first well is a true well, for the other shafts only serve the purpose of aeration pits and maintenance shafts that facilitate access of maintenance workers to the gallery system. ${ }^{73}$ In order to ensure a perennial water supply, mother wells were probably dug during the month of August because in Mediterranean and Near-Eastern countries the water table will be at its lowest levels. ${ }^{74}$ In Persia, the excavators of qanat formed part of a hereditary class of professionals who were highly respected. ${ }^{75}$ In some instances it appears that the expert diggers, also referred to as muqanni, had to be prepared to travel long distances in order to fulfil their duties. ${ }^{76}$ After the digging of the mother well, they calculated where the mouth of the gallery was to be located, and considered the amount of land surface area to be irrigated from the projected qanat.

\footnotetext{
${ }^{65}$ Watson, op. cit. in note 62, I o8-9; C. S. Beekman, P. C. Weigand and J. J. Pint, 'Old World irrigation technology in a New World context: qanats in Spanish colonial western Mexico’, Antiquity, 73 (I 999), 440-66, 440. See also Glick, op. cit. in note 64, I $75^{-97}$.

${ }_{66}$ Hodge, op. cit. in note 6r, 2 I; Glick, op. cit. in note 6I, I82.

${ }^{67}$ Hodge, op. cit. in note $61,22$.

${ }^{68}$ Glick, op. cit. in note 64, I 75.

${ }^{69}$ Ibid., I 75-82.

${ }^{70}$ Beekman et al., op. cit. in note 65,440 .

${ }^{71}$ Horden et al., op. cit. in note $59,23^{8}-4^{2}$.

${ }^{72}$ Beekman et al., op. cit. in note $65,44 \mathrm{I}$.

73 Glick, op. cit. in note 64,182 .

${ }^{74}$ Glick, op. cit. in note 48, 238 .

${ }^{75}$ Beekman et al., op. cit. in note $65,44 \mathrm{I}$.

${ }^{76}$ Horden et al., op. cit. in note 59, 252.
} 
Tools were basic: picks, shovels, baskets and small lamps. The digging of the horizontal canal would normally commence from the point where the water was to exit the canal, and heads towards the mother well. The correct gradient of the gallery, which generally varies between I:I,000 to I: I,500, was established using string alignments and simple levels. Qanat tunnels are generally not more than I $\mathrm{m}$ wide and I.5 $\mathrm{m}$ high, but may extend underground for kilometres on end. A gutter or channel in the floor of the tunnel usually carries water to the gallery entrance. ${ }^{77}$ In order to facilitate both access and airflow into the underlying horizontal canals, vertical shafts were often dug beforehand and were generally spaced between I5 to I50 m apart. Excavated debris could also be hauled up. ${ }^{78}$ The excavation of qanats is a lengthy process. A modern, three $\mathrm{km}$-long qanat in Iran recorded in the mid-2oth century, capable of supplying enough water for half an acre of land to be irrigated once every 24 hours, took seventeen years to complete. ${ }^{79}$ The longest known qanat at Gonabad (Iran) is around $35 \mathrm{~km}$ long. ${ }^{80}$

The Latium and Veii regions in Italy have dense concentrations of complex systems of subterranean galleries, which are essentially very similar in structure and technological principle to qanat. Better known as cuniculi, their real use and function has long baffled archaeologists. ${ }^{81}$ Like qanat, cuniculi are composed of a near horizontal main tunnel, the roof of which is pierced by a series of vertical rectangular shafts. All cuniculi are excavated in volcanic tufo, ${ }^{82}$ which readily erodes when exposed to weathering and water action, ${ }^{83}$ and similarly to qanats are generally slightly more than $0.5 \mathrm{~m}$ wide and around I.75 m high. Nonetheless, there are records of cuniculi being twice as wide. ${ }^{84}$ Vertical shafts are generally spaced between $3 \mathrm{I}$ to $34 \mathrm{~m}$ one from the other and, in areas where the tufo was recognised as being too weak, it was occasionally re-enforced by means of bricks or masonry. The direction of the toolmarks preserved on the gallery wall suggests that the method of excavation of these subterranean galleries differs substantially from that of qanats. The tunnel excavation did not commence at the gallery entrance, but started from the base of a shaft from where diggers proceeded in opposite directions towards other shafts. It is unknown whether the shaft was simply used as a device that facilitated cuniculi construction or also as a means through which the galleries could be accessed for easier maintenance. ${ }^{85}$

\footnotetext{
77 Hodge, op.cit. in note 6I, 23.

${ }^{78}$ Beekman et al., op. cit. in note $65,44 \mathrm{I}$.

${ }^{79}$ Horden et al., op. cit. in note 59, 238-9.

${ }^{80}$ Hodge, op. cit. in note $6 \mathrm{I}, 23$.

${ }^{81}$ Horden, op. cit. in note $59,247$.

${ }^{82}$ The ejecta resulting from a volcanic eruption consists of accumulations of volcanic ash, cinders and mudflow deposits.

${ }^{83}$ One possible reason for digging cuniculi in a tufo deposit is the fact that this makes water sweet and light and acts as a strainer, keeping back the dirt: Pliny, Natural History, Lib. xxxi, 47-8, ed. and trans. W. H. S. Jones, Pliny - Natural History (Harvard, I 989), 407-9.

84 S. Judson and A. Kahane, 'Underground Drainage in Southern Etruria and Northern Latium', Pap. Brit. School Rome, xxxi (I 963), 74-103, 78-99.

85 Ibid., 84-55.
} 
Cuniculi are difficult to date, but surviving evidence points towards the Etruscan and the Roman period. An account by Livy dating to the Ist century B.C. reports on cuniculi as being military devices aimed at facilitating access into besieged cities. ${ }^{86}$ It is unclear whether Pliny the Elder's mention of underground tunnels used for the carrying of water and which should have vents every $73 \mathrm{~m}$ $(240 \mathrm{ft})$ is a reference to cuniculi. ${ }^{87}$ These underground passageways remained in use at least till the end of the Roman Empire, but there is isolated evidence that similar systems were also used in late-medieval Italy. Scholars generally have divergent views on the use of cuniculi. ${ }^{88}$ The use of this intricate network of subterranean galleries as a means of irrigation is debatable, but there is evidence to suggest their use for a multitude of other purposes, namely land and lake drainage together with urban and domestic drainage needs. At times, cuniculi were attached to aqueducts or used as a means from which to obtain power for water-driven mills, amongst other water-powered devices. It appears they were also used as military devices and road tunnels. ${ }^{89}$

Even though at first glance cuniculi and qanat appear to be closely related, a close comparison of both hydrological devices reveals several basic differences. Cuniculi are hewn into volcanic tufo and are located in a wet latitude containing plentiful water deposits. Qanat are situated in arid and semi-arid limestone regions. Qanat were exclusively used as a means through which an underground water supply could be tapped as an aid to agriculture and to nearby human settlements and were normally hewn at right angles to valley sides. In order to allow the irrigation of the underlying fields, qanats were furthermore located at a suitable altitude, at a higher level than the land to be irrigated. By contrast, most of the cuniculi studied in the Latium and Veii area move in a direction parallel to that of the valley and are located at a relatively low height, almost at level to the valley bed. ${ }^{90}$

F. Ravelli and P. Howarth argue that the primary function of cuniculi was to collect potable water, purified by filtering action while seeping through tufo and soil deposits. ${ }^{91} \mathrm{~S}$. Judson and A. Kahane suggest that a single cuniculus might have served a multitude of functions but that the majority of these underground systems were designed as an aid to agricultural installations. ${ }^{92}$ Cuniculated land was originally too wet to allow effective agriculture, and that is why artificial drainage was necessary. And in the absence of structures at the mouth of the subterranean tunnels which can be associated with the storage of water or its distribution, it is unlikely that cuniculi were used for the collection of water or irrigation. Well-planned qanats are able to supply a perennial water source,

\footnotetext{
86 Ibid., 74 .

${ }^{87}$ Pliny, op. cit. in note 83,4 I 2-I 5 .

${ }^{88}$ For a more detailed discussion on the age of the cuniculi: F. Ravelli and P. J. Howarth, 'Etruscan cuniculi: tunnels for the collection of pure water', Trans. Twelfth Int. Congress Irrigation Drainage, 2 ( 1984$)(<\mathrm{http}$ ://www. francoravelli.it> last accessed 28 April 2007); Judson et al., op. cit. in note 84, 74-IO3.

89 Ibid., 89 .

90 Ibid., 74-103.

${ }^{91}$ Ravelli et al., op. cit. in note 89 .

${ }^{92}$ Judson et al., op. cit. in note $84,74-\mathrm{I} 03$.
} 
but most cuniculi carry water when it is not really needed for crop growth and run low on water during the summer months. Furthermore, the majority of the cuniculi end in narrow segments of valleys where there is only a limited area of arable land. ${ }^{93}$ Similar conclusions were reached by A. T. Hodge who moreover states that another function of cuniculi was that of lowering the water table level in the subsoil. ${ }^{94}$

\section{INTERPRETING THE EVIDENGE}

The dating of the Maltese galleries is a task that requires great caution. One means of dating these galleries abroad is by the chemical analysis of mortar retrieved from within these underground structures. ${ }^{95}$ It is not yet known if any of the Maltese galleries are lined with mortar, and a tailor-made database, compiled from the analysis of mortar samples originating from secure contexts, is necessary if such an endeavour is to be successful. The galleries' continuous use and the lack of internal stratified deposits seem to provide little scope for their archaeological investigation.

Not all the galleries in any given area are necessarily coeval, but it appears that the majority of these artificial water springs are not recent efforts attempting to increase the agricultural yield of the specifically selected areas..$^{96}$ The majority of present farmers are unaware of the dynamics through which galleries extract water from the perched aquifer and some are ignorant of the existence of a gallery on their property. Interviews with farmers owning land irrigated by water retrieved from these galleries have confirmed that these were present in their property within living memory of their grandfather or great grandfather. A farmer cultivating land beneath the $\mathrm{W}$. ravine at Il-Qlejgha tal-Bahrija is totally unaware of the existence of two walled-up galleries in her property, and simply refers to the perennial spring as, 'water gushing out of a crevice'. Another farmer owning land in Gnien San Niklaw in the outskirts of Mellieha cannot understand how a gallery that irrigates his land yields such voluminous quantities of water, and put forward his theory that the water originates from Sicily. Most of the farmers have probably never explored the entire gallery network, but occasionally carry out maintenance work on the outer sections of the water tunnel. The farming communities who cultivate the land still maintain most identified galleries and keep them in good working order.

I have consulted water data sheets and maps compiled by the local water company between I943 and r949. These contain information on all public and many of the then extant private galleries, wells and springs. All private springs

\footnotetext{
${ }^{93}$ Ibid., 89-9 I.

${ }^{94}$ Hodge, op. cit. in note 6I, 45-7. In a landscape study of the Tuscia region in central Italy, Paolo Dalmiglio also associates the function of cuniculi in the area with that of land drainage and tentatively dated them to the

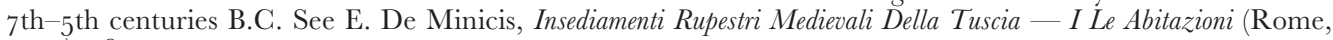
2003), $3^{8-4}$ I.

95 Glick, op. cit. in note 64 , I 89-90.

${ }_{96}$ A securely locked metal door in the region of Dingli cliffs probably conceals the entrance to a gallery. The lintel above the doorway contains the date igo i painted in black paint.
} 
should have been registered in I947, but a surprising number of the water sources were omitted from this stock-taking exercise. Many of the water galleries detected during the course of my study were marked on the I940s data sheets as 'old springs' and are simply described as 'water flowing by gravity from a natural rock opening'.

It is possible that the galleries are the result of new hydrological technology introduced in the islands by the Knights of the Order of St John. The tall screening walls surrounding the garden, together with a number of fruit trees in Gnien ta' Baldu in the upper section of Wied ir-Rum, were presumably planted a few decades before the publication of Abela's work in $1647 \cdot{ }^{97}$ Nonetheless, the siting of the garden was probably possible due to the availability of a reliable perennial water supply originating from various galleries in Wied ir-Rum, probably dating to the later Medieval Period, which could maintain a stable ecosystem. The spring of Aajn Tejtes, mentioned by Abela, owes as its source a water gallery in Giardino di S. Giacomo. Abela's mention of a cave yielding water in the Giardino la Kattara, is another possible reference to a gallery, even though the water tunnel is not directly referred to. ${ }^{98}$ Ghajn Tajba, ${ }^{99}$ in the outskirts of Mtahleb, similarly originates from a gallery. Abela's brief description of the Dejr el Binet tenement, in the outskirts of Dingli, leaves no doubt as to the gallery's existence before I 647 and the alleged disappearance of several young women inside the intricate network of subterranean tunnels was already regarded as popular tradition. ${ }^{100}$ Another gallery at the Ta' Baldu tenement supplied a nearby circular cave, utilised as a bath, with water. ${ }^{101}$ In the absence of a proper archaeological exploration of the area, both cave and gallery are difficult to date, but are possibly coeval in date to the Arab occupation of the island. ${ }^{102}$

Irrigation from perennial water sources by gravity flow canals was a technology shared by all peoples of the Mediterranean basin. ${ }^{103}$ This hydraulic technique appears to have been widely used in antiquity. The Romans used qanat in conjunction with aqueducts to provide urban areas with a reliable water supply. A Roman qanat system built near Murcia (SE. Spain) was also described by the late-I 3 th-century Arab chronicler, al-Himyarï. ${ }^{104}$

A study of the available documentation seems to suggest that sections of the Maltese Islands were intensely cultivated in Arab times (I Ith and I 2th centuries), when new horticultural skills were also introduced. ${ }^{105}$ The climatic unity of the Mediterranean, which allowed the transfer of landscapes from one

\footnotetext{
${ }_{97}$ Abela, op. cit. in note 45,65 .

${ }^{98}$ Ibid., 65 .

99 Ibid., 66.

100 Abela (ibid., 65) describes the tenement as, 'Case chiamate delle donzelle, perche quiui in una caverna, dalle quale scaturisce un fonte, dicesi, che si smarrissero alcune fanciulle, che colà entrate non seppero poscia ritrovar l'uscita' (Houses called of the dames, because tradition relates how, in a cave from which a spring flows, several young girls (maidens) were lost. On entering the cave, they did not manage to locate the exit).

${ }^{101}$ K. Buhagiar, 'The Roman Baths at Ta' Baldu Tenement', Treasures Malta, 6:2 (2000), 47-5 I.

102 Buhagiar, op. cit. in note $1,164-73$.

103 Glick, op. cit. in note 48,96 .

104 Ibid., 224-7.

105 S. Fiorini, 'Malta in I 530', I I I-98 in V. Mallia-Milanes (ed.), Hospitaller Malta (Malta, i 993), i I 5-I6; A. Bonanno, 'L' Habitat Maltese in Età Romana', $K \Omega K A \Lambda O \Sigma$, xxı-Xxiı ( I $976-7)$, 385-95, 392-3.
} 
sector of the basin to another, probably made this possible. The familiar ecological context helped migrants to establish themselves in new territories without any substantial change in their settlement patterns, agricultural practices and diet. ${ }^{106}$ Moreover, Muslims exploited soils and micro-climates which were previously not utilised to their full potential, through the introduction of new crops and the importation of the necessary hydraulic technology capable of sustaining them. ${ }^{107}$

The local practice of terracing the land flanking the sides of valleys was probably unknown in Roman and Byzantine times, ${ }^{108}$ and is commonly attributed an Arab origin. In the study area, the terracing of the land and location of galleries appear to be closely related. The galleries are hydrological devices, very similar in nature to qanat, and are generally located slightly higher or at level with the uppermost terraced field on the sides of valleys possessing the necessary geologic stratification. This was in order to enable the irrigation of the underlying land without the need of the employment of water-lifting devices, such as the noria. We have to seriously consider the possibility that Arabs introduced the galleries during their occupation of Malta. Qanat technology together with the required technical expertise, possibly filtered into Malta through the neighbouring island of Sicily. I have noted a water gallery identical to those recorded in Malta in the Sicilian settlement of Enna.

This possibility is further aided by linguistic considerations, which hint that the Maltese agricultural terminology possibly originated in this period, ${ }^{109}$ although it must be noted that none of the words are documented before the mid-I $5^{\text {th }}$ century and many are rather later, that is well after Arabic times.

Medieval Muslim jurisprudents in various Mediterranean settlements took great care in classifying the land according to whether it was irrigated or not. This was done in order to be able to tax the land accordingly. The land which was not watered artificially and which depended exclusively on rainfall was called $b a^{\prime} l$, while the irrigated land was called saqi. ${ }^{110}$ The Maltese language distinguishes the irrigated landscape from the non-irrigated one by the words baghli and saqwi. ${ }^{111}$

It appears that several Maltese words and toponyms have a close affinity to the word qanat. The singular of the word qonja in the Maltese language is qana and literally means a medium through which water is transported. It is most commonly associated with a pipe, water canal and aqueduct. ${ }^{12}$ 'Ta' Qana' is the toponym of a field at Hal Saflieni meaning '[The field] of the drain hole', recorded in $\mathrm{I}_{523}$ by notary $\mathrm{C}$. Canchur. ${ }^{113}$ The toponym of an unlocated district, 'Ta' Bir il-Qannata', 114 recorded in I 540 by notary Juliano Muscat, is

\footnotetext{
106 Glick, op. cit. in note 48,55 .

107 Ibid., 55.

108 Bonanno, op. cit. in note I 05, 392-3.

109 Fiorini, op. cit. in note I 05, I I 6.

110 Glick, op. cit. in note $48,83-4$.

${ }^{111}$ Serracino-Inglott, op. cit. in note $48,462$.

112 Ibid., 462.

113 Wettinger, op. cit. in note 49, 433.

114 Ibid., 48.
} 
also significant and perhaps refers to a gallery and an adjoining reservoir for the storage of water. 'Ta' Qannotta' is an unlocated district recorded in I520 by Not. Gr. Vassallo, ${ }^{15}$ while 'Wied Qannotta' is a valley located between Zebbiegh and Burmarrad first recorded by notary J. Sabbara in I $496 .{ }^{116}$ Wettinger excludes any relationship between 'qana' and 'Wied Qannotta', ${ }_{117}$ but it would be interesting to establish whether 'Ghajn Hamiem' to the north-west of Mdina, overlooking the old Mtarfa railway station, first recorded in 1436 and meaning 'the spring at the [public] baths', originates from a water gallery. ${ }^{118}$ 'Ghar Ilma' close to Ghammar in Gozo contains a water gallery. It remains nonetheless unclear whether other 'Ghar Ilma' place-names, for which there are four instances in Malta, contain galleries. ${ }^{19}$

\section{CONCLUSIONS}

Over the last two decades, historical and archaeological research has registered progress in the Maltese medieval field of study, ${ }^{120}$ but the archaeological potential of the local countryside is still barely considered and the past human impact and exploitation of large tracts of the island's rural landscape and resources remain unstudied. This field survey has identified various isolated settlements, most of which were previously unrecorded and which probably reflect a long established life-pattern of exploiting caves for settlement and associated water retrieval and management techniques. Although by no means a conclusive study, I hope it will lead to an increased awareness of the archaeological potential preserved in the surviving tracts of the Maltese countryside.

None of the elements of this landscape is yet scientifically dated, but comparative work suggests that, because of their similarities to qanat design, it is possible the galleries were introduced in Saracen or sub-Saracen times during the course of the i ith to the i $3^{\text {th }}$ centuries. People only abandoned the majority of the caves studied in the first half of the 2oth century, but they have probably been subject to continuous use since the late Middle Ages. Further scientific investigation is necessary to establish the potential of the caves, galleries and field systems to answer our questions. It is likely that most of the cave-units only preserve shallow deposits on their interior, and these probably lack stratification. The investigation of the terraced land fronting the settlements may be a more fruitful exercise. Surface counts of potsherds can lead to the identification of a settlement's dumping ground, while the excavation of terraces fronting caves and which contain abundant soil deposits can lead to the discovery of stratified layers. The present lack of a reliable medieval pottery typology will prove a hindrance to future studies; this is still a work in

\footnotetext{
115 Ibid., 434.

116 Ibid., 583 .

117 Ibid., I 84 .

118 Pers. comm. Prof. Godfrey Wettinger.

119 Il-Qallelija, Wardija, Tal-Handaq and Msida are four districts in Malta in which the toponym of Ghar Ilma occurs: Wettinger, op. cit. in note 49, 206.

120 A. Luttrell, The Making of Christian Malta (Aldershot, 2002), I-I 7.
} 
progress. ${ }^{121}$ The potentially productive medieval sites of San Pawl Milqi and Tas-Silg, excavated in the r 960 , are still not fully published. ${ }^{122}$ The archaeological investigation of the Gozo Citadel, a key medieval site that may probably furnish the medieval archaeologist with a reliable pottery typology, still awaits scholarly attention.

It is only through the investigation of several of the identified gallery networks that we can establish their potential in yielding stratified deposits. Their exploration will help establish the widespread use of ventilation and service shafts, which pierce the roof of galleries at intervals, within a local context. The chemical analysis of mortar is widely used in the dating of water galleries abroad, ${ }^{123}$ and the availability of a local mortar typology might not only help in the dating of galleries and cave units, but also in that of cisterns, funerary complexes and masonry built structures. The accurate dating of field terracing is still to be attempted.

The subterranean galleries, associated field systems and at least some of the caves appear to be related and to have common origins in the exploitation of the agricultural landscape, their location being conditioned by availability of the exposed Mtarfa Member deposit and the identification and exploitation of nearby subterranean water deposits from the perched aquifer. All cave-settlements are located on high ground and command unobstructed views of the underlying terraced land, most of which was probably cultivated by the troglodytes. The isolated nature of several cave-settlements hints to the possibility that their occupants practised a subsistence-type of agriculture and the surrounding land provided all the necessary amenities. It is possible that people used several of the studied caves as a temporary shelter, but most appear to have housed farming communities in the Early Modern Period, and I would argue, Late Middle Ages too.

\section{AGKNOWLEDGEMENTS}

The obligations incurred in the writing of this paper are many. I am deeply indebted to my M.A. supervisor Prof. Mario Buhagiar of the University of Malta and Dr Richard Reece, formerly of the Institute of Archaeology, University of London for their prompt advice and constant support and encouragement. I am also grateful to Prof. Paul Arthur of Lecce University for providing feedback on an earlier version of this paper. A word of gratitude also goes to the Maltese farmers, without whose co-operation and permission to access their property, this work would not have been possible.

\footnotetext{
${ }^{121}$ Ibid., 6. See also A. Molinari and N. Cutajjar, 'Of Greeks and Arbas and of Feudal Knights', Malta Archaeol. Rev., 3 (I 999), 9-I5.

${ }^{122}$ Luttrell, op. cit. in note I 20, 4 .

123 Glick, op. cit. in note 64, I 89-90.
} 